DISPOSITIONAL AND SITUATIONAL FACTORS AT WORK: A VALIDATION OF SCALES AND EXAMINATION OF EFFECTS ON JOB SATISFACTION

\title{
Lucas Pujol-Cols
}

Consejo Nacional de Investigaciones Cientificas y Tecnicas, Tandil, Argentina and Vicerrectoría de Investigación y Postgrado, Universidad Católica del Maule, Curicó, Chile

\section{Guillermo E. Dabos}

Facultad de Ciencias Económicas, Universidad Nacional del Centro de la Provincia de Buenos Aires, Tandil, Argentina and Universidad de San Andres, Argentina

\section{Please cite this article as:}

Pujol-Cols, L, \& Dabos, G. E. (2019). Dispositional and situational factors at work: A validation of scales and examination of effects on job satisfaction. Academia Revista Latinoamericana de Administracion. Advance online publication. doi: https://doi.org/10.1108/arla-12-2017-0355 


\title{
DISPOSITIONAL AND SITUATIONAL FACTORS AT WORK: A VALIDATION OF SCALES AND EXAMINATION OF EFFECTS ON JOB SATISFACTION
}

\begin{abstract}
Purpose - The purpose of this paper is to examine the psychometric properties of the Spanish version of the Core Self-Evaluations Scale (CSES) and the Brief Index of Affective Job Satisfaction (BIAJS) in terms of internal consistency and factor structure and to, subsequently, analyze the influence of a set of dispositional factors (namely, core selfevaluations, CSEs) and situational factors (namely, psychosocial factors) on job satisfaction.
\end{abstract} Methods - 209 academics from an Argentinian university completed online surveys at two stages, separated in time, to reduce the common method bias.

Findings - The Spanish version of the CSES and the BIAJS showed acceptable psychometric properties, which were similar to those previously reported in North-American, European and Asian settings. Hierarchical regression analyses revealed that both situational and dispositional factors are significant predictors of job satisfaction.

Research implications - The CSES and the BIAJS seem to be valid and reliable instruments to assess core self-evaluations and job satisfaction, respectively, in Latin America. The adoption of an interactionist approach that includes both situational and dispositional factors is crucial in future research examining job satisfaction.

Practical implications - Managers should carefully evaluate the personality traits of candidates during personnel selection, as well as the working conditions they offer to their employees, since both factors seem to affect job satisfaction.

Originality - This article contributes to the validation of two scales that may promote future organizational behavior/psychology research in Latin America. In addition, it provides empirical evidence of the relative influence of a set of situational and dispositional factors on job satisfaction, thus contributing to the resolution of the person-situation debate. 
Type - Research paper.

Keywords: CLADEA 2017, Core Self-Evaluations, Psychosocial Risks, Job Satisfaction.

\section{INTRODUCTION}

Job satisfaction is one of the most studied phenomena of the 20th century, particularly in organizational behavior/psychology research. In fact, as Judge, Weiss, Kammeyer-Mueller, and Hulin (2017) pointed out in their recent review, job satisfaction has been mentioned in more than seventy percent of the articles included in the PsycINFO database, remaining one of the most frequently featured keywords in the Journal of Applied Psychology. This sustained interest in job satisfaction partly reflects the managerial and scholarly concerns to improve organizational effectiveness, given the abundant evidence linking job satisfaction with several attitudes and outcomes, such as absenteeism, turnover, organizational citizenship, organizational commitment, and performance (e.g., Diestel, Wegge and Schmidt, 2014; Flickinger, Allscher and Fiedler, 2016; Tziner, Waismal-Manor, Vardi and Brodman, 2008; Ziegler, Hagen and Diehl, 2012). However, there is also an ethical impetus to improve job satisfaction, as it has been found to be significantly associated with individuals' psychological and physical well-being (e.g., Grant, Wardle and Steptoe, 2009; Tsaousis, Nikolaou, Serdaris and Judge, 2007).

Job satisfaction has been defined in a variety of ways in the literature, resulting, for instance, in contradictory arguments as to whether this complex construct involves emotional processes, cognitive processes, or both (see Pujol-Cols and Dabos, 2018, for a review). Thus, although some authors like Weiss (2002) have defined job satisfaction as a positive or negative evaluative judgement that the individual formulates about the different facets of a job (i.e., cognitive job satisfaction), in this article we follow Fisher (2000)'s argument that job satisfaction represents an individual's affective or emotional response towards his job as a whole (i.e., affective job satisfaction). 
For over three decades, theories attempting to trace the antecedents of job satisfaction have generated a great deal of controversy (Judge and Zapata, 2015). Indeed, there is still little agreement on whether the person or the situation is more influential in predicting individuals' job satisfaction (see the concept of person-situation debate in Kenrick and Funder, 1988). On the one hand, situational research has mostly focused on the influence that organizational variables exert on employees' attitudes and behaviors (Dierdorff and Morgeson, 2013). From this perspective, job design, that is to say, the way work is structured, perceived, experienced, and performed (Grant, Fried and Juillerat, 2010), affects job satisfaction (Bowling, Khazon, Meyer and Burrus, 2015), as it exposes individuals to varying degrees of psychosocial risks, which, if not successfully managed, may lead to the experience of strain (Unda, Uribe, Jurado, García, Tovalín, and Juárez, 2016). As psychosocial risks, these work-related factors either by excess, defect, or combination pose a threat to the physical, social, or psychological integrity of employees (Meliá, Nogareda, Lahera, Duro, Peiró, Salanova and Gracia, 2006). It is worth noting that psychosocial risks and their effects on job satisfaction have received a great deal of attention in situational research, mainly as a result of the profound transformations that have affected employment relationships in recent years. Specifically, the so-called Copsoq-Istas model, developed by the Spanish Trade Union Institute of Work, Environment and Health (Moncada et al., 2004), has become one of the most widely used taxonomies of psychosocial risks, mainly as a result of its exhaustiveness and parsimony (Pujol-Cols and Arraigada, 2017, Pujol-Cols and Lazzaro-Salazar, 2018).

On the other hand, dispositional research has mainly focused on the role that personality plays on individuals' attitudes and behaviors in the workplace. More specifically, dispositionalism claims that individuals have a set of relatively stable, unobservable mental states (which are linked to their personality traits) that affect the job satisfaction they are likely to experience across a wide variety of organizational settings (Judge, Klinger, Simon 
and Yang, 2008b; Ones, Dilchert, Viswesvaran and Judge, 2007). Indeed, dispositional literature argues that individuals tend to be consistent in their attitudes towards their job even in the presence of different organizational conditions (Barrick, 2005). Although several personality taxonomies have been proposed so far in the literature (e.g., positive/ negative affectivity, Brief, Butcher and Robertson, 1995; big five personality traits, Goldberg, 1990), a more recent construct, called core self-evaluations (CSEs, Judge, Locke and Durham, 1997), has also proven to significantly explain job satisfaction in numerous studies (e.g., Judge, Heller, and Klinger, 2008a; Judge, Ilies, and Zhang, 2012; Wu and Griffin, 2012). Specifically, CSEs refer to a set of essential and unconscious assessments that individuals make about themselves, others and their environment (Judge, Erez, Bono and Thoresen, 2003).

Since the beginning of the person-situation debate, both dispositional and situational approaches have demonstrated the merit of their arguments (Judge and Zapata, 2015), suggesting that each theoretical perspective is relevant and, therefore, should be considered in studies addressing job satisfaction (Cohrs, Abele and Dette, 2006). However, to date, interactionist studies on job satisfaction are still very limited, as most of them have mainly focused on examining the effects of one set of factors in isolation (see Lent and Brown, 2006 and Pujol-Cols and Dabos, 2018 for a detailed review). Moreover, most of this research has concentrated on a relatively narrow set of work factors, which were mainly intrinsic in nature (e.g., Hackman and Oldham, 1976), thus ignoring, to a considerable extent, the influence of other extrinsic work factors that are also relevant to explain job satisfaction (Humphrey et al., 2007). As Staw and Cohen-Charash (2005) argued, the adoption of an interactionist perspective, that contemplates a more comprehensive set of situational and dispositional factors, is not only vital to better understand job satisfaction, but also to overcome methodological problems like model misspecification, which occurs when models ignore the 
influence of relevant predictors. This last point is not trivial, as model misspecification may lead to overestimating the effects of explanatory variables, thus leading to misinterpretations regarding their magnitude and significance (see Bernerth and Aguinis, 2016). In this sense, Staw and Cohen-Charash (2005) suggested that one way of solving the person-situation debate is to design competitive tests that evaluate and compare the magnitude and significance of the effects of both sets of factors on job satisfaction.

Thus, with the aim of advancing our understanding of the factors that lead to job satisfaction, this article examines, on the one hand, the psychometric properties of the Spanish version of the Core Self-Evaluations Scale (CSES; Judge et al., 2003) and the Brief Index of Affective Job Satisfaction (BIAJS; Thompson and Phua, 2012) for the first time in Latin America, and, on the other hand, the relative influence of a set of situational and dispositional factors on job satisfaction.

\section{THEORETICAL BACKGROWD AND HYPOTHESIS DEVELOPMENT}

\section{The dispositional approach}

Personality, that is to say, those personal characteristics of individuals that determine consistent ways of feeling, thinking, and behaving (Mayer, 2007; Pervin, Cervone and John, 2005), has been given considerable attention in the job satisfaction literature, particularly in the last two decades (Judge, Klinger, Simon and Yang, 2008b; Ones et al., 2007). From a dispositional perspective, individuals possess a set of unobservable mental states, called dispositions, that are relatively stable over time (Caspi, Roberts and Shiner, 2005; Dormann, Fay, Zapf and Frese, 2006) as they have strong genetic (Johnson et al., 2009; Judge et al., 2012) and neuropsychological bases (Pickering and Gray, 1999), that affect their attitudes and behaviors at work (Judge et al. al., 2008b). In particular, core self-evaluations (CSEs), understood as a set of basic, essential, and unconscious conclusions that individuals make 
about their own worthiness, competence, and capabilities (Judge et al., 2003 ), is the most novel personality taxonomy that has proven to significantly explain job satisfaction (Wu and Griffin, 2012).

As a broad, latent, and higher-order construct, CSEs reflect four personality traits that are well established in psychology research (see Judge, Locke, Durham, and Kluger, 1998). First, there is self-esteem, understood as an overall measure of value that the individual formulates about himself as a person (Harter, 1990). Second, there is self-efficacy, which represents the degree of confidence that individuals have about their competence to perform tasks effectively and attain goals successfully (Bandura, 1997). Third, there is internal locus of control, which reflects the extent to which individuals believe that most of the events that occur in their lives are the result of their own behavior (Rotter, 1966). By feeling that most of these events are under their control, these individuals are also more likely to associate positive events with their own merits and efforts. Finally, emotional stability (or low neuroticism) represents individuals' tendency to focus on the more positive aspects of themselves, others and their lives (Costa and McCrae, 1988). In this sense, emotionally stable individuals tend to focus on their success, rather than on their failures, as well as on the most favorable aspects of their job.

Numerous studies have reported high correlations (e.g., Judge, Erez, Bono and Thoresen, 2002) and a unidimensional structure (e.g., Judge, Bono and Locke, 2000) underlying the four traits of CSEs. These findings motivated Judge, Erez, Bono and Thoresen (2003) to develop the Core Self-Evaluations Scale (CSES), which was specifically designed to examine CSEs as a global phenomenon through 12 items. It is worth noting that the CSES has not only been drawn on an extensive literature review (see Judge et al., 1997 and Judge et al., 1998), which is a fundamental indicator of content validity, but has also exhibited 
satisfactory psychometric properties in several studies (see Pujol-Cols and Dabos, 2018, for a detailed review).

From Judge et al. (1997)'s seminal contributions to this day, CSEs have been studied in a variety of organizational settings and countries (e.g., Stumpp et al., 2010; Dormann et al., 2006; Piccolo et al., 2005; Rode, Judge and Sun, 2012), which has provided evidence of the universality of the construct and the cross-cultural generalizability of its effects on job satisfaction. Despite the interest that the international literature has shown in this line of research, it was not possible to find any previous study that examined the relationship between CSEs and job satisfaction in Latin America. However, the international literature has shown at least three mechanisms through which CSEs are expected to affect job satisfaction. First, individuals with more positive CSEs tend to focus on the more positive aspects of their job, to perceive them in a more favorable way and to react more positively to them, thus experiencing higher job satisfaction (Judge et al., 1998; Cohrs et al., 2006). Second, people with more positive CSEs tend to select more complex and challenging jobs, which affects the kind of experiences they are likely to have in the workplace and, consequently, their job satisfaction (Kristof-Brown, Zimmerman and Johnson, 2005; Sunal, Sunal and Yasin, 2011; Srivastava, Locke, Judge and Adams, 2010). Finally, individuals with higher CSEs tend to perceive the characteristics of their job as less stressful and to experience less strain than those with more negative CSEs (Spector et al., 2000), which is expected to lead to higher levels of job satisfaction (Hsieh and Huang, 2017; Kammeyer-Mueller et al., 2009). Based on the evidence presented in this section, it follows that:

Hypothesis 1 (H-1): CSEs will be positively and significantly related to job satisfaction.

\section{The situational approach}

Situationalism, which originated in the years after the Second World War, argues that organizations represent strong situations (Meyer, Dalal and Hermida, 2010), as they exert a 
powerful influence on the behavior and attitudes of employees (Humphrey et al., 2007; Morgeson and Humphrey, 2006). From this perspective, job design, that is to say, the set of processes and results underlying the organization, experimentation and performance of work (Grant et al., 2011), prescribes and/or stimulates the emergence of a set of psychosocial factors, which affect the job satisfaction of employees by exposing them to varying degrees of psychosocial risks. As stated by Meliá et al. (2006), these psychosocial risks either by excess, defect, or combination, pose a threat to the physical, social or psychological integrity of individuals. The Copsoq-ISTAS model, developed by the Spanish Trade Union Institute of Work, Environment and Health (ISTAS; Moncada, Llorens and Kristensen, 2004), is one of the most widespread taxonomies of psychosocial risks in the Ibero-American literature. In the 1.5 version of this model, Moncada et al. (2004) proposed six work-related factors that often pose risks to the physical and psychological health of employees.

The first factor, named psychological demands, reflects the volume and intensity of workload (i.e., quantitative psychological demands), as well as those aspects of the job that require a sustained emotional effort (i.e., emotional psychological demands). Regarding quantitative demands, there is evidence that work overload tends to lead to the experience of distress and, as a result, to job dissatisfaction (Klassen and Chiu, 2010). On the other hand, those occupations involving high emotional demands tend to lead to emotional dissonance (i.e., the conflict between expressed and genuinely felt emotions) and, consequently, to lower levels of job satisfaction (Lewig and Dollard, 2003).

The second factor, called work control, reflects the extent to which the job gives the employee opportunities for autonomy and development. The positive effects of autonomy on job satisfaction have been recognized for decades in the management literature (e.g., Ferguson and Cheek, 2011; Humphrey et al., 2007; Morgeson and Humphrey, 2006). Indeed, and drawing on the principles of the self-determination theory, autonomy constitutes a universal 
psychological need that nourishes the intrinsic motivation of individuals (Gagne and Deci, 2005), which leads them to experience more positive states, such as job satisfaction (Humphrey et al., 2007). Conversely, insufficient levels of autonomy are expected to be associated with reductions in individuals' intrinsic motivation and job satisfaction (Skaalvik and Skaalvik, 2014).

The third factor, named social support and leadership, refers to the extent to which the individual feels instrumentally and emotionally supported by their superiors and peers. In this regard, there is considerable evidence on the vital role that social support assumes in the job satisfaction and well-being of employees (Häusser, Mojzisch, Niesel and Schulz-Hardt, 2010), particularly in the face of highly stressful working conditions (Wrzesniewski, Dutton and Debede, 2003), as it is expected to mitigate the psychosocial impact of job demands (Kinman et al., 2011). Since social support is not only essential for effective performance (Collins, 2007), but also highly instrumental for fulfilling various emotional (e.g., emotional venting; Carver, Scheier and Weintraub, 1989) and social needs (e.g., sense of belonging; Heaney and Israel, 2008), it is expected that those employees who perceive lower levels of this job resource tend to experience more negative states, such as reductions in their job satisfaction (Harris, Winskowski and Engdahl, 2007).

Double presence is the fourth factor of the model and reflects the degree to which the individual experiences incompatible demands between work and family roles, which causes participation in both roles to become more difficult. Increasing levels of competition among organizations worldwide have forced their employees to work under highly demanding conditions (Salanova et al., 2005), which has reduced, therefore, their ability to cope with family demands while also leading a successful career path (Goh, Ilies, and Schwind Wilson, 2016). Indeed, work overload increases the likelihood of work-family conflict, as the role pressures coming from both domains tend to become mutually incompatible (Greenhaus and 
Allen, 2011). In this regard, previous research has demonstrated that work-family conflict is associated with reductions in employees' job satisfaction (Ilies, Schwind, Wagner, Johnson, De Rue and Ilgen, 2007).

The fifth factor, named job insecurity, represents the employee's prolonged concern about the continuity of his current working conditions. In this regard, there is considerable evidence that job insecurity is a fundamental antecedent of job dissatisfaction (Reisel, Probst, Chia, Maloles and Konig, 2010), especially among part-time employees (Waltman, Bergom, Hollenshead, Miller and August, 2012). Thus, since working is highly instrumental for fulfilling a wide range of basic and superior needs (Weir, 2013), perceptions of higher job insecurity are expected to be associated with increasing experienced distress (Mauno, Leskinen and Kinnunen, 2001) and, consequently, with lower job satisfaction levels (Sverke, Hellgren and Naswall, 2002).

The sixth and last factor of the model, named esteem, refers to the extent to which the employee feels that the rewards and recognition they receive are fair in regards to the contributions they make. In this regard, numerous studies have long demonstrated that a perceived lack of reciprocity between efforts and rewards is a fundamental source of distress (Siegrist, 1996). Moreover, subsequent meta-analytic studies have revealed that the degree to which participants feel that rewards such as pay, recognition, and career opportunities are fairly distributed in the organization (i.e., distributive justice) plays an essential role in their job satisfaction levels (Cohen-Charash and Spector, 2001). In a similar vein, Gillespie, Walsh, Winefield and Stough (2001) reported that a perceived imbalance between effort and rewards constitutes one of the greatest sources of occupational distress and job dissatisfaction. Based on the ideas presented in this section, we hypothesize that:

Hypothesis 2 (H-2): Those psychosocial factors representing job resources (i.e., autonomy, esteem, social support and quality of leadership) will be positively and 
significantly related to job satisfaction, whereas those representing job demands (i.e., psychological demands, double presence, job insecurity) will be negatively and significantly related to job satisfaction.

\section{The interactionist approach}

As argued by Funder et al. (2012), the person-situation debate builds on the false assumption that persons and situations are two competing domains, thus claiming that individuals' attitudes and behavior are, in fact, the result of the influence of both factors. In this sense, individuals are shaped by the characteristics of job design but they also maintain their individuality. Despite the fact that the arguments supporting interactionism have increased substantially in recent years (Judge and Zapata, 2015), empirical studies examining the joint effects of both personality and situational factors on job satisfaction have not only been limited (Cohrs, Abele, and Dette, 2006; Funder et al., 2012; Lent and Brown, 2006) but also inconsistent (Chang, Ferris, Johnson, Rosen and Tang, 2012; Hsieh and Huang, 2017). To provide an example, Dormann et al. (2006) reported that $62 \%$ of the variance in job satisfaction is explained by situational variables, whereas only $24.25 \%$ seems to be explained by a more stable set of factors, like dispositions. Conversely, Thomas, Buboltz and Winkelspecht (2004) reported that none of the traits included in the Myers-Briggs Personality Type Indicator (Myers, McCaulley, Quenk and Hammer, 1998) were significant predictors of job satisfaction, once a set of intrinsic work characteristics (i.e., autonomy, variety) was entered in the hierarchical regressions. Moreover, a study conducted by Cohrs et al. (2006) revealed that only two situational variables, namely autonomy and participatory leadership, and one dispositional variable, namely occupational self-efficacy, significantly explained job satisfaction once all the variables included in the study were taken into consideration. More recently, Nguyen and Borteyrou (2016) reported that dispositions explained incremental 
variance in job satisfaction once situational variables such as job demands and autonomy were controlled.

There are several reasons that could explain the inconsistencies discussed above. First, the majority of interactionist studies have favored, more or less subtly, one set of factors over the other (Haney and Zimbardo, 2009). Second, most of interactionist research has avoided examining the relative influence of both dispositional and situational variables on job satisfaction by conducting competitive tests (Staw and Cohen-Charash, 2005). Third, interactionist studies have mostly analyzed the effects of intrinsic situational factors (i.e., task characteristics), thus ignoring, to a considerable extent, the effects of extrinsic work factors (i.e., those relating to the physical, social, and organizational context in which tasks are performed) that have also proven to explain job satisfaction (Humphrey et al., 2007; Hogan, 2009). Fourth, some of these studies have relied on ad-hoc scales to assess situational work factors, instead of using generic taxonomies that allow researchers to compare findings across various organizational contexts, occupations, and countries (Buss, 2009). In spite of the aforementioned limitations, and drawing on the evidence presented so far, we propose that:

Hypothesis 3 (H-3). Both dispositional and situational factors will explain incremental variance in job satisfaction.

\section{METHOD}

\section{Participants}

Two hundred and nine academics from an Argentinian public university participated in this study. The age of the participants ranged from 23 to 70 years, with an average (standard deviation in parentheses) of 44.40 (11.76). The majority of the participants $(69.86 \%)$ were women. Regarding the participants' positions, $36.36 \%$ were professors, $19.62 \%$ were senior tutors and $44.02 \%$ were tutors. Moreover, $24.88 \%$ of the respondents had a full-time contract. 
Participants' overall tenure ranged from 1 to 45 years, with an average of 17.49 (10.51). Their tenure in the current position ranged from 1 to 30, with an average of 8.66 (8.41). In regards to the participants' level of education, $69.38 \%$ had an undergraduate degree, $19 \%$ had a Master's degree and 12\% had a Ph.D.

\section{Procedure}

Following approval of the study from the highest academic authorities of the university, an online survey was sent to 414 academics through an online link to a Google Drive ${ }^{\mathrm{TM}}$ form that was provided by email. The survey included a description of the aims of the study and an online consent form. It also included an email address in case participants had any concern, query or suggestion. Access to the digital survey was only granted to those academics who had authorized their participation by accepting the consent form. Although invitations were sent from an institutional email address, participants were reminded that responses to the survey were confidential (see Declaration of Helsinki, 1964 and Declaration of Singapore, 2010). Following the procedure in Judge et al. (2005) to reduce the common method bias, data were collected in two stages. First, the participants were invited to answer a questionnaire on CSEs. Second, and two weeks later, they were invited to answer a survey on job satisfaction and psychosocial risks. A total of 209 individuals completed both surveys over a five-month period (response rate $=50.48 \%$ ).

\section{Variables and instruments}

Core self-evaluations were examined with the Core Self-Evaluations Scale (CSES; Judge et al., 2003). It consisted of twelve items (see Appendix) and a five-point Likert scale ( 1 = totally disagree, $5=$ totally agree). The individual scores of the twelve items were averaged to form a single CSE score. 
Job satisfaction was measured with the Brief Index of Affective Job Satisfaction (BIAJS; Thompson and Phua, 2012). It consisted of four items (see Appendix) and a 5-point Likert scale $(1=$ totally disagree, $5=$ totally agree $)$. The individual scores of the four items were averaged to form a single overall job satisfaction score.

Psychosocial factors were examined with the reduced version of the Copsoq-Istas Psychosocial Risk Questionnaire (Moncada et al, 2004; also see Pujol-Cols and Arraigada, 2017). It consisted of 38 items with a response scale ranging from 0 (never/ to a very small extent) to 4 (always/ to a very great extent). It is worth noting that this instrument has been specifically designed to measure employees' perceived exposure to six major categories of psychosocial risks, namely, psychological demands (6 items), work control (10 items), social support and leadership (10 items), double presence (4 items), esteem (4 items), and job insecurity (4 items). The total score for each factor was calculated by averaging the scores of their respective items.

\section{Translation of scales}

In order to use the CSES and the BIAJS in the Argentinian context, we translated both instruments from English into Spanish by following a simplified version of the procedure in Hambleton, Merenda and Spielberger (2006). Thus, and taking into consideration that the translated items should capture the linguistic meaning of those included in the original survey (Muñiz, Elosua and Hambleton, 2013), we asked for the assistance of a professional translator who had postdoctoral training in Linguistics, was native in both Spanish and English, and had numerous publications on interculturality (see Acknowledgments). Both the authors and the bilingual advisor separately translated and back-translated (see Brislin, 1980) the instruments from English (e.g., "I am confident I get the success I deserve in life") into Spanish (e.g., "Me siento confiado en que obtengo el éxito que merezco en la vida"). These three independent translations and back-translations were then compared and differences were solved through 
mutual agreement. Instead of pretending a literal translation, we intended that the translated items maintained the meaning of those included in the original surveys (i.e., cultural and linguistic equivalence; see Behling and Law, 2000; Muñiz et al., 2013). The Spanish version of both scales are available to the reader in the Appendix.

\section{Data analysis}

We analyzed the reliability of the CSES and the BIAJS in terms of internal consistency by calculating Cronbach's alpha coefficient. In regards to the factor structure of both scales, we conducted a confirmatory factor analysis (CFA) in two stages. First, we verified that our data was appropriate for using CFA (Hair, Anderson, Tatham and Black, 1995) by calculating the Kaiser-Meyer-Olkin measure of sample adequacy (KMO) and Bartlett's sphericity test. Second, we examined the dimensionality of the CSES and the BIAJS through a CFA with structural equations using a maximum likelihood estimation method (Brown, 2006). The data were processed in IBM SPSS AMOS (version 22).

To analyze the relative influence of situational factors (i.e., psychosocial factors) and dispositional factors (i.e., CSEs) on job satisfaction, we conducted hierarchical regression analyses following Aiken, West and Reno (1991). We first verified that our data was appropriate for performing regression analysis, by testing the assumptions of normality (Shapiro-Wilk test), homoscedasticity (Breusch-Pagan test) and non-multicollinearity (Variance Inflation Factor, VIF). Additionally, we tested for common method bias by calculating Harman's one-factor test. The data were processed in IBM SPSS (version 24).

\section{RESULTS}

\section{Descriptive analysis and psychometric properties}

Means, standard deviations, and correlations among the variables of study are reported in Table 1. As can be seen, CSEs exhibited a positive and statistically significant relationship 
with job satisfaction, indicating that higher CSEs were associated with higher levels of job satisfaction. In addition, CSEs displayed positive correlations with those psychosocial factors representing job resources (i.e., work control, social support and leadership, and esteem) and negative correlations with those factors representing job demands (i.e., psychological demands, double presence, and job insecurity), indicating that those individuals with more positive CSEs tended to perceive a lower level of exposure to psychosocial risks. On the other hand, those psychosocial factors representing job resources exhibited positive and statistically significant correlations with job satisfaction. The opposite was observed for those factors representing job demands.

INSERT TABLE 1 ABOUT HERE

As shown on the main diagonal of Table 1, the Spanish version of the CSES exhibited a satisfactory internal consistency ( $\alpha=0.80$; see Nunnally and Bernstein, 1994), which was similar to that reported in previous research conducted in other countries (e.g., Judge et al., 2003; Stumpp et al., 2010). Regarding the factor structure of the CSES, previous studies (e.g., Judge et al., 2003) have shown that its twelve items should reflect one single latent factor. In order to test the unidimensionality of the CSES, we performed a CFA with structural equations in AMOS (version 22). We followed Byrne (2001)'s recommendations to report and compare different fit indices, such as the chi-square statistic $\left(\chi^{2}\right)$, the comparative fit index $(\mathrm{CFI})$, the goodness of fit index (GFI) and the root mean square error of approximation (RMSEA). CFI and GFI values above .90 and RMSEA values as high as .08 indicate a good fit (Byrne, 2001). The results revealed that the unidimensional model provided an acceptable fit to the data $\left(\chi^{2}=112.81, \mathrm{df}=54, \mathrm{p}<.01, \chi^{2} / \mathrm{df}=2.09, \mathrm{CFI}=.88, \mathrm{GFI}=.92, \mathrm{RMSEA}=\right.$ 
.07). In addition, these findings were consistent with those reported in Judge et al. (2003)'s validation study (CFI values between .87 and .95 , GFI values between .88 and .94 . and RMSEA values between .05 and .08). In regards to the Spanish version of BIAJS, the results demonstrated that this instrument also showed a satisfactory internal consistency $(\alpha=0.83)$, which was similar to that reported by Thompson and Phua (2012) for the original scale $(\alpha=$ 0.85). Regarding its factor structure, since affective job satisfaction is a unidimensional construct that reflects an employee's emotional response towards the job as a whole (Fisher, 2000), we hypothesized that the four items of the BIAJS would load into a single latent factor. Consistently with previous research in Anglo-Saxon settings, the results of the CFA revealed that the unidimensional model provided a satisfactory fit to the data $\left(\chi^{2}=12.11\right.$, $\mathrm{df}=2, \mathrm{p}<$ $.01, \mathrm{CFI}=.97, \mathrm{GFI}=.97, \mathrm{RFI}=.90, \mathrm{TLI}=.91)$.

\section{Common method bias}

Since perceived exposure to the six psychosocial factors and job satisfaction were measured at the same time, which could cause common method bias, we conducted Harman's one-factor test, by simultaneously entering these variables into an exploratory factor analysis. The results revealed that the single factor only accounted for $26.01 \%$ of the total variance, which is lower than the critical level suggested by Podsakoff, McKenzie, Lee and Podsakoff (2003). These findings indicated that the results of this study were not significantly affected by the common method bias.

\section{Effects of dispositional and situational factors on job satisfaction}

To compare the relative influence of dispositional and situational factors on job satisfaction we performed a series of hierarchical regression analyses. As a preliminary step, we verified that the data complied with the assumptions of normality, homoscedasticity, and non-multicollinearity (see Table 2). 
Following Aiken et al. (1991), we conducted the hierarchical regression analyses in three stages. In model 1 , we only computed the control variables. In model 2 , we entered the dispositional factors (i.e., CSE) along with the control variables, reflecting a dispositional perspective. In model 3, we computed the situational factors (i.e., psychological demands, work control, social support and leadership, double presence, esteem, and job insecurity) along with the control variables, thus adopting a purely situational perspective. Finally, in model 4, we computed the dispositional and situational factors simultaneously, reflecting an interactionist perspective (see Table 2).

Only those variables that showed statistically significant correlations with job satisfaction were introduced as control variables in model 1 (see Table 1), being these: (a) age, (b) gender (base group = women), and (c) hierarchy (base group = participants without a professorship). As shown in Table 2, gender was the only control variable that was statistically significant, meaning that men were, on average, less satisfied with their job than women.

In model 2 (which accounted for $21 \%$ of the variance in job satisfaction, see $\mathrm{R}^{2}$ coefficient in Table 2), we introduced CSEs along with the control variables (reflecting a dispositional perspective). The results revealed that the dispositional factor explained an additional $14 \%$ (see the variations in the adjusted $\mathrm{R}^{2}$ coefficient in Table 2 ) in the variability of job satisfaction (i.e., CSEs had a positive effect on satisfaction even after the control variables were taken into consideration), thus supporting H-1. In model 3 (which accounted for $30 \%$ of the variance in job satisfaction, see the $\mathrm{R}^{2}$ coefficient in Table 2 ), we entered the six psychosocial factors along with the control variables (reflecting a situational perspective). The results revealed that the situational factors explained an additional $21 \%$ in the variability of job satisfaction (see the variations in the adjusted $\mathrm{R}^{2}$ coefficient in Table 2), thus providing partial support to $\mathrm{H}-2$. 
In model 4 (which accounted for $34 \%$ of the variance in job satisfaction, see the $\mathrm{R}^{2}$ coefficient in Table 2), we entered both CSEs and psychosocial factors simultaneously into the regressions to examine their partial effects on job satisfaction (which reflects an interactionist perspective). As shown in Table 2, CSEs remained statistically significant, even after the situational factors and control variables were introduced in the regressions, supporting H-3. Regarding the psychosocial factors, only two of them (i.e., work control and esteem) were statistically significant, which partially supported H-3. Moreover, as shown in Table 2, the explained variance in job satisfaction significantly increased when both dispositional and situational factors were taken into account (adjusted $\mathrm{R}^{2}=.31, \mathrm{p}<.01 ; \Delta$ adjusted $\mathrm{R}^{2}$ model $2-$ model $4=.12, \mathrm{p}<.01 ; \Delta$ adjusted $\mathrm{R}^{2}$ model $3-$ model $\left.4=.05, \mathrm{p}<.01\right)$, which provided empirical support to the importance of using an interactionist approach when addressing job satisfaction.

INSERT TABLE 2 ABOUT HERE

To examine whether the results of model 4 could vary across age groups, we split our sample in two independent groups (i.e., participants younger or older than 40 years; see Table 3). The results were quite similar across groups, although esteem remained statistically significant only in group 1. Furthermore, the effects of CSEs on job satisfaction were found to be weaker in group 1 than in group 2.

INSERT TABLE 3 ABOUT HERE 


\section{DISCUSSION AND CONCLUSIONS}

Although over thirty years have passed since the person-situation debate was first introduced in the literature, the controversy between dispositionalism and situationalism seems to be far from ending (Judge and Zapata, 2015). On the one hand, situational literature has argued that most of dispositional research has not adequately controlled for important situational factors that are likely to affect job attitudes (Davis-Blake and Pfeffer, 1989; Funder et al., 2012), claiming that, under strong organizational situations, the effects of personality on job satisfaction are expected to become insignificant (Cooper and Withey, 2009). On the other hand, situational research has been criticized for being excessively focused on the intrinsic aspects of the job (Humphrey et al., 2007), using arbitrary taxonomies and ad hoc scales (Buss, 2009; Reis, 2008), and avoiding the treatment of personality in their models (Staw and Cohen-Charash, 2005). This article, then, extended the existing literature by analyzing and comparing the relative influence of a set of dispositional and situational factors on job satisfaction. Situational factors were examined through a set of psychosocial factors that reflected both intrinsic and extrinsic aspects of the job (i.e., psychological demands, work control, social support and leadership, double presence, esteem, and job insecurity). Dispositional factors were measured through CSEs, a personality taxonomy that has attracted considerable attention in organizational psychology research in recent years (Judge et al., 2008b).

In the first place, the results of this study showed that CSEs remained statistically significant across all models, even after the situational factors and control variables were entered into the regressions. These findings provided support to $\mathrm{H}-1$ and $\mathrm{H}-3$ and were consistent with previous research reporting the existence of a dispositional source of job satisfaction (e.g., Stumpp et al., 2010; Dormann et al., 2006; Wu and Griffin, 2012). There are numerous reasons why CSEs are expected to be positively and significantly related to job 
satisfaction. As argued by Judge et al. (1998) "core self-evaluations are the base on which situationally specific appraisals occur" (pp. 31), which means that those individuals with more positive CSEs are more likely to see and evaluate the different domains of their lives, including their job, more positively. Indeed, these individuals are more prone to experience job satisfaction as they: (a) have higher self-esteem and, consequently, see themselves as deserving greater happiness; (b) are more self-efficacious, thus being more confident in their abilities to overcome the most challenging and difficult aspects of their job; (c) have an internal locus of control and, as a result, tend to associate the more positive outcomes of their job with their own merits and efforts; (d) have higher emotional stability, thus being less likely to focus on their shortcomings, as well as on the more negative aspects of their job (Srivastava et al., 2010).

The findings of this study also showed that work control and esteem were the only significant situational predictors of job satisfaction, with the first exhibiting the strongest partial effect. Although autonomy and esteem have already been suggested as relevant predictors of job satisfaction in numerous studies conducted from a mainly situational approach (e.g., Dierdorff and Morgeson, 2013; Edwards et al., 2000; Morgeson and Humphrey, 2006), the present study demonstrated that both variables explain incremental variance in job satisfaction, above and beyond dispositional and control variables, which provided partial support to H-2 and H-3. Thus, when employees feel they can exert more influence on their job or that the rewards they receive are fair in regards to the contributions they make, they are more likely to experience higher job satisfaction, as they become more intrinsically motivated and work engaged (Gagné and Deci, 2005; Humphrey et al., 2007; Cohen Charash and Spector, 2001; Harris et al., 2007).

We cannot help but wonder why double presence and psychological demands, which showed the highest prevalence in the sample of this study, were not significant predictors of 
job satisfaction. These findings could possibly be explained by the characteristics of the occupational context in which this research was conducted. For instance, participants may have felt that the high psychological demands they face when performing their work roles (e.g., teaching undergraduate and postgraduate courses, grading exams, leading research projects), as well as the double presence that arises as a consequence, are both an inherent part of their profession, thus playing a less relevant role in their job satisfaction. Conversely, participants may have felt that their employers could make a bigger effort in improving their working conditions by providing them with the appropriate autonomy and rewards. Thus, the findings of this study demonstrated that the degree to which participants perceive that they can exert a significant influence on the design and performance of their work roles, as well as the extent to which they feel that they are fairly rewarded, really make a difference in their job satisfaction. These results are consistent with previous research conducted in Argentinian universities, which revealed that most academics feel that the salary, opportunities for career development, and recognition they receive are unfair in regards to the contributions they make (e.g., Fernández Lamarra and Marquina, 2013; García de Fanelli and Moguillansky, 2014; Pujol-Cols and Lazzaro-Salazar, 2018; Pujol-Cols and Arraigada, 2017).

The results of this study also showed that when both situational and dispositional factors are introduced simultaneously their explanatory power on job satisfaction increase significantly, suggesting that both sets of factors should be considered in future research on job satisfaction. These results are consistent with previous studies (although most of them have adopted either a dispositional or a situational standpoint) and, at the same time, provide empirical support to adopting an interactionist perspective when examining job satisfaction (e.g., Funder et al., 2012).

The second contribution of this article lied in the examination of the psychometric properties of the CSES and the BIAJS for the first time in the Argentinian context. First, the 
results showed that the Spanish version of the CSES exhibited a satisfactory internal consistency, which was similar to that reported in previous research conducted in other countries (e.g., Stumpp et al., 2010; Judge et al., 2003). Regarding its dimensionality, the results of the CFA provided an adequate support to the one-factor model that has been previously suggested in the literature (e.g., Dormann et al., 2006; Judge et al., 2003; Piccolo et al., 2005). Moreover, the findings demonstrated that CSEs displayed positive and statistically significant correlations with job satisfaction, which was also consistent with previous research (e.g., $\mathrm{Wu}$ and Griffin, 2012) and provided evidence of the predictive validity of the CSES. In regards to the Spanish version of the BIAJS, the results revealed that it also exhibited a satisfactory internal consistency, which was similar to that reported in Thompson and Phua (2012). Furthermore, the four items of the BIAJS reflected a unidimensional structure, which was consistent with Fisher (2000)'s propositions regarding affective job satisfaction.

\section{Implications for practice}

Our results have strong implications for practice. On the one hand, it is essential that managers do an appropriate assessment of the personality of candidates during personnel selection, as it significantly affects the job satisfaction that individuals are prone to experience. On the other hand, the results of this study also indicated that an effective personnel selection process is not enough to achieve high levels of job satisfaction in the workplace, being vital that organizations carefully design the working conditions they offer to their employees with the aim of mitigating their psychosocial impact on job satisfaction. In particular, the findings of this study suggested that managers should pay special attention to the levels of autonomy and esteem that they provide to their employees, as both factors are relevant predictors of job satisfaction. 


\section{Limitations and future research directions}

This study has some limitations that should be noted. First, it was drawn on crosssectional data, which prevents the authors from postulating cause-effect relationships between the examined variables. Instead, future research could use longitudinal designs to further explore the directionality of the relationships proposed in this article (see $\mathrm{Wu}$ and Griffin, 2012). Second, the sample used to conduct this study consisted exclusively of skilled workers, who usually have access to high levels of autonomy and work flexibility, which, in some way, could compromise the generalizability of the results to other organizational contexts or occupations. Future research should draw on more heterogeneous samples of employees, who are exposed to a wider range of working conditions. Third, and though this study contemplated both intrinsic and extrinsic situational factors, it could be argued that there are other work factors (e.g., emotional dissonance, see Lewig and Dollard, 2003; labor differentiation policies, see Rivero and Dabos, 2017) that may also be relevant to explaining job satisfaction and were not considered in the empirical analyses. Future research could examine the influence of other relevant situational factors or decompose the six aggregated dimensions used in this study into more specific categories. Furthermore, future studies could also add objective measures of situational factors, for example, by conducting a more systematic analysis of participants' working conditions. Fourth, the dispositional and situational effects examined in this study were mainly direct. Future studies should further explore the possible mediating or moderating influence of other variables in the relationships proposed in this article. Finally, the psychometric properties of the CSES and the BIAJS were examined only in terms of internal consistency and factor structure. Future studies should further test the validity of these instruments in the Latin American context by analyzing their convergent validity, discriminant validity, and stability in various samples of employees from different industries and occupations. 


\section{Concluding remarks}

This study demonstrated that the Spanish version of the CSES and the BIAJS exhibit adequate psychometric properties, in terms of reliability and dimensionality, in the Latin American context. In addition, the results also revealed that employees' perceptions regarding their working conditions (especially in terms of autonomy and esteem) are relevant to explaining their job satisfaction, regardless of their personality. Finally, the findings of this study also demonstrated that employees' dispositional traits, such as their personality, play a fundamental role in their job satisfaction, so that they can maintain a positive attitude towards their job even in the face of psychosocial risks.

\section{Acknowledgements}

The authors would like to thank the academics who participated in this study and Dr. Mariana Lazzaro-Salazar (Universidad Católica del Maule, Chile, and Victoria University of Wellington, New Zealand) for her assistance in the translation of the CSES and the BIAJS.

\section{REFERENCES}

Aiken, L.S., West, S.G. and Reno, R.R. (1991), Multiple regression: Testing and interpreting interactions, Sage, Newbury Park, CA.

Bandura, A. (1997), Self-efficacy: The exercise of control, W. H. Freeman, New York.

Barrick, M. R. (2005), "Yes, personality matters: Moving on to more important matters", Human Performance, Vol. 18 No. 4, pp. 359-372.

Behling, O., and Law, K. S. (2000), Translating questionnaires and other research instruments: Problems and solutions, Sage, Thousand Oaks, CA.

Bernerth, J. B. and Aguinis, H. (2016), “A critical review and best-practice recommendations for control variable usage", Personnel Psychology, Vol. 69 No.1, pp. 229-283. 
Bowling, N. A., Khazon, S., Meyer, R. D., and Burrus, C. J. (2015), "Situational strength as a moderator of the relationship between job satisfaction and job performance: A metaanalytic examination", Journal of Business and Psychology, Vol. 30 No. 1, pp. 89104.

Buss, D. M. (2009), “An evolutionary formulation of person-situation interactions”, Journal of Research in Personality, Vol. 43 No. 2, pp. 241-242.

Brief, A. P., Butcher, A. H. and Roberson, L. (1995), "Cookies, disposition, and job attitudes: The effects of positive mood-inducing events and negative affectivity on job satisfaction in a field experiment", Organizational Behavior and Human Decision Processes, Vol. 62 No. 1, pp. 55-62.

Brislin, R. W. (1980), "Translation and content analysis of oral and written materials", En Triandis, H. C. y Berry, J. W. (Eds.), Handbook of cross-cultural psychology, Allyn \& Bacon, Boston, pp. 389-444.

Brown, T. A. (2006), Confirmatory factor analysis for applied research, Guildford Press, New York.

Byrne, B. M. (2001), "Structural equation modeling: Perspectives on the present and the future”, International Journal of Testing, Vol. 1 No. 3-4, pp. 327-334.

Carver, C. S., Scheier, M. F. and Weintraub, J. K. (1989), “Assessing coping strategies: a theoretically based approach", Journal of Personality and Social Psychology, Vol. 56 No. 2, pp. 267-283.

Caspi, A., Roberts, B. W. and Shiner, R. L. (2005), "Personality development: Stability and change”, Annual Review of Psychology, Vol. 56 No. 1, pp. 453-484.

Chang, C. H., Ferris, D. L., Johnson, R. L., Rosen, C. C. and Tan, J. A. (2012), “Core selfevaluations: A review and evaluation of the literature", Journal of Management, Vol. 38 No. 1, pp. 81-128. 
Cohen-Charash, Y., and Spector, P. E. (2001), "The role of justice in organizations: A metaanalysis", Organizational Behavior and Human Decision Processes, Vol. 86 No. 2, pp. 278-321.

Cohrs, J. C., Abele, A. E., and Dette, D. E. (2006), “Integrating situational and dispositional determinants of job satisfaction: Findings from three samples of professionals", The Journal of Psychology, Vol. 140 No. 4, pp. 363-395.

Collins, S. (2007), "Statutory social workers: Stress, job satisfaction, coping, social support and individual differences", British Journal of Social Work, Vol. 38 No. 6, pp. 11731193.

Costa, P. T, Jr. and McCrae, R. R. (1988), "Personality in adulthood: A six-year longitudinal study of self-reports and spouse ratings on the NEO Personality Inventory", Journal of Personality and Social Psychology, Vol. 54 No. 1, pp. 853-863.

Davis-Blake, A. and Pfeffer, J. (1989), "Just a mirage: The search for dispositional effects in organizational research", Academy of Management Review, Vol. 14 No. 3, pp. 385400.

Dierdorff, E. C., and Morgeson, F. P. (2013), “Getting what the occupation gives: Exploring multilevel links between work design and occupational values", Personnel Psychology, Vol. 66 No. 3, pp. 687-721.

Diestel, S., Wegge, J., and Schmidt, K. H. (2014), "The impact of social context on the relationship between individual job satisfaction and absenteeism: The roles of different foci of job satisfaction and work-unit absenteeism”, Academy of Management Journal, Vol. 57 No. 2, pp. 353-382.

Dormann, C., Fay, D., Zapf, D., and Frese, M. (2006), “A state-trait analysis of job satisfaction: on the effect of core self-evaluations", Applied Psychology, Vol. 55 No. 1, pp. $27-51$. 
Edwards, J. R., Scully, J. A., and Brtek, M. D. (2000), “The nature and outcomes of work: a replication and extension of interdisciplinary work-design research", Journal of Applied Psychology, Vol. 85 No. 6, pp. 860-868.

Fritzsche, B. A. and Parrish, T. J. (2005), “Theories and research on job satisfaction”, En Brown, S. D. y Lent, R. W. (Eds.), Career development and counseling: Putting theory and research to work, Wiley, Hoboken, NJ, pp. 180-202.

Ferguson, T. D., and Cheek, R. (2011), "How Important Are Situational Constraints in Understanding Job Satisfaction?", International Journal of Business and Social Science, Vol. 2 No. 22, pp. 221-227.

Fernández Lamarra, N. and Marquina, M. (2013), "La Profesión Académica en America Latina: Tendencias actuales a partir de un estudio comparado", Espacios en blanco. Serie indagaciones, Vol. 23 No. 1, pp. 99-117.

Fisher, C. D. (2000), "Mood and emotions while working: Missing pieces of job satisfaction?", Journal of Organization Behavior, Vol. 21 No. 1, pp. 185-202.

Flickinger, M., Allscher, M., and Fiedler, M. (2016), “The mediating role of leader- member exchange: a study of job satisfaction and turnover intentions in temporary work", Human Resource Management Journal, Vol. 26 No. 1, pp. 46-62.

Funder, D., Guillaume, E., Kumagai, S, Kawamoto, S., and Sato, T. (2012), "The Personsituation Debate and the Assessment of Situations", The Japanese Journal of Personality, Vol. 21 No. 1, pp. 1-11.

Gagné, M., and Deci, E. L. (2005), "Self- determination theory and work motivation", Journal of Organizational Behavior, Vol. 26 No. 4, pp. 331-362.

García de Fanelli, A. and Moguillansky, M. (2014), "La docencia universitaria en Argentina Obstáculos en la carrera académica”, Education Policy Analysis Archives, Vol. 22 No. 1, pp. 1-18. 
Gillespie, N. A., Walsh, M. H. W. A., Winefield, A. H., Dua, J., and Stough, C. (2001), "Occupational stress in universities: Staff perceptions of the causes, consequences and moderators of stress", Work \& Stress, Vol. 15 No. 1, pp. 53-72.

Goh, Z., Ilies, R., and Wilson, K. S. (2015), "Supportive supervisors improve employees' daily lives: The role supervisors play in the impact of daily workload on life satisfaction via work-family conflict”, Journal of Vocational Behavior, Vol. 89 No. 1, pp. 65-73.

Goldberg, L. R. (1990), “An alternative "description of personality": the big-five factor structure", Journal of Personality and Social Psychology, Vol. 59 No. 6, pp. 12161229.

Grant, N., Wardle, J., and Steptoe, A. (2009), “The relationship between life satisfaction and health behavior: a cross-cultural analysis of young adults", International Journal of Behavioral Medicine, Vol. 16 No. 3, pp. 259-268.

Grant, A.M., Fried, Y. and Juillerat, T. (2011), "Work matters: Job design in classic and contemporary perspectives", En Zedeck, S., APA Handbook of Industrial and Organizational Psychology, American Psychological Association, Washington, DC.

Greenhaus, J. H., and Allen, T. D. (2011), "Work-family balance: A review and extension of the literature", Handbook of Occupational Health Psychology, Vol. 2 No. 1, pp. 165183.

Hackman, J. R. and Oldham, G. R. (1976), "Motivation through the design of work: Test of a theory", Organizational Behavior and Human Performance, Vol. 16 No. 2, pp. 250279.

Hair, J., Anderson, R., Tatham, R., and Black, W. (1995), Multivariate data analysis, Prentice-Hall, Englewood Cliffs, NJ. 
Hambleton, R. K., Merenda, P. F., and Spielberger, C. D. (2006), Adapting Psychological and Educational Tests for Cross-Cultural Assessment, Lawrence Erlbaum Associates, Mahwah.

Haney, C. and Zimbardo, P. G. (2009), "Persistent dispositionalism in interactionist clothing: Fundamental attribution error in explaining prison abuse", Personality and Social Psychology Bulletin, Vol. 35 No. 6, pp. 807-814.

Harter, S. (1990), "Causes, correlates, and the functional role of global self-worth: A lifespan perspective", En Sternberg, R. J. and Kolligan, J. (Eds.), Competence considered, Yale University Press, New Haven, CT, pp. 67-97.

Harris, J. I., Winskowski, A. M. and Engdahl, B. E. (2007), “Types of workplace social support in the prediction of job satisfaction", The Career Development Quarterly, Vol. 56 No. 2, pp. 150-156.

Harrison, D. A., Newman, D. A., and Roth, P. L. (2006), “How important are job attitudes? Meta-analytic comparisons of integrative behavioral outcomes and time sequences", Academy of Management Journal, Vol. 49 No. 2, pp. 305-325.

Häusser, J. A., Mojzisch, A., Niesel, M., and Schulz-Hardt, S. (2010), “Ten years on: A review of recent research on the Job Demand-Control (-Support) model and psychological well-being”, Work \& Stress, Vol. 24 No. 1, pp. 1-35.

Heaney, C. A. and Israel, B. A. (2008), "Social networks and social support", Health Behavior and Health Education, Vol. 4 No. 1, pp. 189-210.

Hogan, R. (2009), "Much ado about nothing: The person-situation debate", Journal of Research in Personality, Vol. 43 No. 2, pp. 249.

Humphrey, S. E., Nahrgang, J. D., and Morgeson, F. P. (2007), "Integrating motivational, social, and contextual work design features: a meta-analytic summary and theoretical 
extension of the work design literature", Journal of Applied Psychology, Vol. 92 No. 5, pp. 1332-1353.

Hsieh, H. H., and Huang, J. T. (2017), "Core self-evaluations and job and life satisfaction: the mediating and moderated mediating role of job insecurity", The Journal of Psychology, Vol. 151 No. 3, pp. 282-298.

Ilies, R., Schwind, K. M., Wagner, D. T., Johnson, M. D., DeRue, D. S., and Ilgen, D. R. (2007), "When can employees have a family life? The effects of daily workload and affect on work-family conflict and social behaviors at home", Journal of Applied Psychology, Vol. 92 No. 5, pp. 1368-1379.

Judge, T. A., Locke, E. A., and Durham, C. C. (1997), "The dispositional causes of job satisfaction: A core evaluations approach", Research in Organizational Behavior, Vol. 19 No. 1, pp. 151-188.

Judge, T. A., Locke, E. A., Durham, C. C. and Kluger, A. N. (1998), "Dispositional effects on job and life satisfaction: the role of core evaluations", Journal of Applied Psychology, Vol. 83 No. 1, pp. 17-34

Judge, T. A., Bono, J. E. and Locke, E. A. (2000), "Personality and job satisfaction: the mediating role of job characteristics", Journal of Applied Psychology, Vol. 85 No. 2, pp. $237-249$

Judge, T. A., Erez, A., Bono, J. E. and Thoresen, C. J. (2002), “Are measures of selfesteem, neuroticism, locus of control, and generalized self-efficacy indicators of a common core construct?", Journal of Personality and Social Psychology, Vol. 83 No. 3, pp. 693-710.

Judge, T. A., Erez, A., Bono, J. E., and Thoresen, C. J. (2003), "The core self-evaluations scale: Development of a measure", Personnel Psychology, Vol. 56 No. 2, pp. 303-331. 
Judge, T. A., Bono, J. E., Erez, A., and Locke, E. A. (2005), “Core self-evaluations and job and life satisfaction: the role of self-concordance and goal attainment", Journal of Applied Psychology, Vol. 90 No. 2, pp. 257-268.

Judge, T. A., Heller, D., and Klinger, R. (2008a), "The dispositional sources of job satisfaction: A comparative test”, Applied Psychology, Vol. 57 No. 3, pp. 361-372.

Judge, T. A., Klinger, R., Simon, L. S., and Yang, I. W. F. (2008b), "The contributions of personality to organizational behavior and psychology: Findings, criticisms, and future research directions", Social and Personality Psychology Compass, Vol. 2 No. 5, pp. 1982-2000.

Judge, T. A., Ilies, R., and Zhang, Z. (2012), “Genetic influences on core self-evaluations, job satisfaction, work stress, and employee health: A behavioral genetics mediated model”, Organizational Behavior and Human Decision Processes, Vol. 117 No. 1, pp. 208-220.

Judge, T. A., and Zapata, C. P. (2015), “The person-situation debate revisited: Effect of situation strength and trait activation on the validity of the big five traits in predicting job performance", Academy of Management Journal, Vol. 58 No. 4, pp. 1-31.

Judge, T. A., Weiss, H. M., Kammeyer-Mueller, J. D., and Hulin, C. L. (2017), “Job attitudes, job satisfaction, and job affect: A century of continuity and of change", Journal of Applied Psychology, Vol. 102 No. 3, pp. 356-374.

Kammeyer-Mueller, J. D., Judge, T. A., and Scott, B. A. (2009), "The role of core selfevaluations in the coping process", Journal of Applied Psychology, Vol. 94 No. 1, pp. 177-195.

Kenrick, D. T., and Funder, D. C. (1988), "Profiting from controversy: Lessons from the person-situation debate", American Psychologist, Vol. 43 No. 1, pp. 23-34. 
Kinman, G., Wray, S., and Strange, C. (2011), "Emotional labour, burnout and job satisfaction in UK teachers: The role of workplace social support", Educational Psychology, Vol. 31 No. 7, pp. 843-856.

Klassen, R. M., and Chiu, M. M. (2010), "Effects on teachers' self-efficacy and job satisfaction: Teacher gender, years of experience, and job stress", Journal of Educational Psychology, Vol. 102 No. 3, pp. 741-756.

Kristof-Brown, A. L., Zimmerman, R. D., and Johnson, E. C. (2005), "Consequences of individuals' fit at work: a meta-analysis of person-job, person-organization, persongroup, and person-supervisor fit”, Personnel psychology, Vol. 58 No. 2, pp. 281-342.

Lent, R. W., and Brown, S. D. (2006), "Integrating person and situation perspectives on work satisfaction: A social-cognitive view", Journal of Vocational Behavior, Vol. 69 No. 2, pp. 236-247.

Lewig, K. A., and Dollard, M. F. (2003), "Emotional dissonance, emotional exhaustion and job satisfaction in call centre workers", European Journal of Work and Organizational Psychology, Vol. 12 No. 4, pp. 366-392.

Mayer, J. D. (2007), "Asserting the definition of personality", The Online Newsletter for Personality Science, Vol. 1 No. 1, pp. 1-4.

Mauno, S., Leskinen, E., and Kinnunen, U. (2001), "Multi- wave, multi- variable models of job insecurity: applying different scales in studying the stability of job insecurity", Journal of Organizational Behavior, Vol. 22 No. 8, pp. 919-937.

Meliá, J. et al. (2006), "Principios Comunes para la Evaluación de los Riesgos Psicosociales en la Empresa", En Meliá, J. et al. (Eds.), Perspectivas de Intervención en Riesgos Psicosociales. Evaluación de riesgos, Foment del Treball Nacional, Barcelona, pp. 1336. 
Meyer, R. D., Dalal, R. S., and Hermida, R. (2010), “A review and synthesis of situational strength in the organizational sciences", Journal of Management, Vol. 36 No. 1, pp. 121-140.

Moncada, S., Llorens, C., and Kristensen, T. S. (2004), Método ISTAS 21 (CoPsoQ). Manual para la evaluación de riesgos psicosociales en el trabajo, Paralelo Ediciones, España.

Morgeson, F. P., and Humphrey, S. E. (2006), “The Work Design Questionnaire (WDQ): developing and validating a comprehensive measure for assessing job design and the nature of work", Journal of Applied Psychology, Vol. 91 No. 6, pp. 1321-1339.

Muñiz, J., Elosua, P., and Hambleton, R. K. (2013), "Directrices para la traducción y adaptación de los tests: segunda edición”, Psicothema, Vol. 25 No. 2, pp. 151-157.

Myers, I. B., McCaulley, M. H., Quenk, N. L., and Hammer, A. L. (1998), MBTI manual: A guide to the development and use of the Myers-Briggs Type Indicator, Consulting Psychologists Press Palo Alto, CA.

Nguyen, N. and Borteyrou, X. (2016), "Core self-evaluations as a mediator of the relationship between person-environment fit and job satisfaction among laboratory technicians", Personality and Individual Differences, Vol. 99 No. 1, pp. 89-93.

Nunnally, J. C. and Bernstein, I. H. (1994), Psychological theory, MacGraw-Hill, New York.

Ones, D. S., Dilchert, S., Viswesvaran, C., and Judge, T. A. (2007), “In support of personality assessment in organizational settings", Personnel Psychology, Vol. 60 No. 4, pp. 995 1027.

Parker, S. K., Wall, T. D., and Cordery, J. L. (2001), "Future work design research and practice: Towards an elaborated model of work design", Journal of Occupational and Organizational Psychology, Vol. 74 No. 4, pp. 413-440.

Pervin, L. A., Cervone, D. and John, O. P. (2005), Personality: Theory and Research, John Wiley \& Sons, Hoboken, NJ. 
Piccolo, R. F., Judge, T. A., Takahashi, K., Watanabe, N., and Locke, E. A. (2005), “Core self-evaluations in Japan: relative effects on job satisfaction, life satisfaction, and happiness", Journal of Organizational Behavior, Vol. 26 No. 8, pp. 965-984.

Pickering, A. D. and Gray, J. A. (1999), “The neuroscience of personality”, In Pervin, L. A. and John, O. P. (Eds.), Handbook of personality: Theory and Research, Guilford Press, New York, pp. 277-299.

Podsakoff, P. M., MacKenzie, S. B., Lee, J. Y. and Podsakoff, N. P. (2003), "Common method biases in behavioral research: a critical review of the literature and recommended remedies", Journal of Applied Psychology, Vol. 88 No. 5, pp. 879-903.

Pujol-Cols, L., and Arraigada, M. (2017), "Propiedades psicométricas del Cuestionario de Riesgos Psicosociales Copsoq-Istas 21 y aplicación en docentes universitarios argentinos", Cuadernos de Administración, Vol. 30 No. 55, pp. 97-125.

Pujol-Cols, L. J., and Dabos, G. E. (2018), “Satisfacción laboral: una revisión de la literatura acerca de sus principales determinantes", Estudios Gerenciales, Vol. 34 No. 146, pp. 3-18.

Pujol-Cols, L. and Lazzaro-Salazar, M. (2018), "Psychosocial Risks and Job Satisfaction in Argentinian Scholars: Exploring the moderating role of Work Engagement”, Journal of Work and Organizational Psychology, Vol. 34 No. 3, pp. 145-156.

Reisel, W. D., Probst, T. M., Chia, S. L., Maloles, C. M., and König, C. J. (2010), “The effects of job insecurity on job satisfaction, organizational citizenship behavior, deviant behavior, and negative emotions of employees", International Studies of Management \& Organization, Vol. 40 No. 1, pp. 74-91.

Rivero, A. G., and Dabos, G. E. (2017), “Gestión diferencial de recursos humanos: una revisión e integración de la literatura", Estudios Gerenciales, Vol. 33 No. 142, pp. 3951. 
Rode, J. C., Judge, T. A., and Sun, J. M. (2012), "Incremental validity of core self-evaluations in the presence of other self-concept traits: An investigation of applied psychology criteria in the United States and China", Journal of Leadership and Organizational Studies, Vol. 19 No. 3, pp. 326-340.

Rotter, J. B. (1966), "Generalized expectancies for internal versus external control of reinforcement”, Psychological Monographs, Vol. 80, No. 1.

Salanova, M., Martínez, I. M., and Lorente, L. (2005), “Cómo se relacionan los obstáculos y facilitadores organizacionales con el burnout docente?: Un estudio longitudinal”, Revista de Psicología del Trabajo y de las Organizaciones, Vol. 21 No. 1-2, pp. $37-$ 54.

Siegrist, J. (1996), "Adverse health effects of high-effort/low-reward conditions", Journal of Occupational Health Psychology, Vol. 1 No. 1, pp. 27-41.

Skaalvik, E. M., and Skaalvik, S. (2014), "Teacher self-efficacy and perceived autonomy: Relations with teacher engagement, job satisfaction, and emotional exhaustion", Psychological Reports, Vol. 114 No. 1, pp. 68-77.

Spector, P. E., Chen, P. Y., and O'Connell, B. J. (2000), “A longitudinal study of relations between job stressors and job strains while controlling for prior negative affectivity and strains", Journal of Applied Psychology, Vol. 85 No. 2, pp. 211-218.

Srivastava, A., Locke, E. A., Judge, T. A., and Adams, J. W. (2010), “Core self-evaluations as causes of satisfaction: The mediating role of seeking task complexity", Journal of Vocational Behavior, Vol. 77 No. 2, pp. 255- 265.

Staw, B. M., and Cohen-Charash, Y. (2005), "The dispositional approach to job satisfaction: More than a mirage, but not yet an oasis", Journal of Organizational Behavior, Vol. 26 No. 1, pp. 59-78. 
Stumpp, T., Muck, P. M., Hülsheger, U. R., Judge, T. A., and Maier, G. W. (2010), "Core self-evaluations in Germany: validation of a German measure and its relationships with career success", Journal of Applied Psychology, Vol. 59 No. 4, pp. 674-700.

Sunal, A. B., Sunal, O. and Yasin, F. (2011), "A comparison of workers employed in hazardous jobs in terms of job satisfaction, perceived job risk and stress: Turkish jean sandblasting workers, dock workers, factory workers and miners", Social Indicators Research, Vol. 102 No. 2, pp. 265-273.

Sverke, M., Hellgren, J., and Näswall, K. (2002), "No security: a meta-analysis and review of job insecurity and its consequences", Journal of Occupational Health Psychology, Vol. 7 No. 3, pp. 242-264.

Thomas, A., Buboltz, W. C., and Winkelspecht, C. S. (2004), "Job characteristics and personality as predictors of job satisfaction”, Organizational Analysis, Vol. 12 No. 2, pp. $205-219$.

Thompson, E. R., and Phua, F. T. (2012), “A brief index of affective job satisfaction”, Group y Organization Management, Vol. 37 No. 3, pp. 275-307.

Tsaousis, I., Nikolaou, I., Serdaris, N., and Judge, T. A. (2007), "Do the core self-evaluations moderate the relationship between subjective well-being and physical and psychological health?”, Personality and Individual Differences, Vol. 42 No. 8, pp. $1441-1452$.

Tziner, A., Waismal-Manor, R., Vardi, N., and Brodman, A. (2008), “The personality dispositional approach to job satisfaction and organizational commitment", Psychological Reports, Vol. 103 No. 2, pp. 435-442.

Unda, S., Uribe, F., Jurado, S., García, M., Tovalín, H. and Juárez, A. (2016), “Elaboración de una escala para valorar los factores de riesgo psicosocial en el trabajo de profesores 
universitarios", Revista de Psicología del Trabajo y de las Organizaciones, Vol. 32 No. 2, pp. 67-74.

Wrzesniewski, A., Dutton, J. E., and Debebe, G. (2003), "Interpersonal sensemaking and the meaning of work", Research in Organizational Behavior, Vol. 25 No. 1, pp. 93-135.

Waltman, J., Bergom, I., Hollenshead, C., Miller, J., and August, L. (2012), "Factors contributing to job satisfaction and dissatisfaction among non-tenure-track faculty", The Journal of Higher Education, Vol. 83 No. 3, pp. 411-434.

Weir, K. (2013), "More than job satisfaction”, APA Monitor on Psychology, Vol. 44 No. 11, pp. 39.

Weiss, H. M. (2002), “Deconstructing job satisfaction: Separating evaluations, beliefs and affective experiences", Human Resource Management Review, Vol. 12 No. 2, pp. 173194.

Wu, C. H., and Griffin, M. A. (2012), "Longitudinal relationships between core selfevaluations and job satisfaction”, Journal of Applied Psychology, Vol. 97 No. 2, pp. $331-342$.

Ziegler, R., Hagen, B., and Diehl, M. (2012), "Relationship between job satisfaction and job performance: Job ambivalence as a moderator", Journal of Applied Social Psychology, Vol. 42 No. 8, pp. 2019-2040. 


\section{APPENDIX}

\section{Spanish version of the Core Self-Evaluations Scale (CSES)}

1. Me siento confiado en que obtengo el éxito que merezco en la vida

2. En ocasiones me siento deprimido/a (puntaje inverso)

3. Cuando lo intento, generalmente lo logro

4. A veces cuando fracaso siento que no sirvo (puntaje inverso)

5. Desarrollo las tareas exitosamente

6. A veces siento que no controlo mi trabajo (puntaje inverso)

7. En general, me encuentro satisfecho/a conmigo mismo

8. Me encuentro lleno/a de dudas acerca de mis capacidades (puntaje inverso)

9. Yo determino qué pasará en mi vida

10. No me siento en control del éxito de mi carrera (puntaje inverso)

11. Soy capaz de enfrentar la mayoría de mis problemas

12. Existen momentos en los que todo me parece bastante desalentador e inútil (puntaje inverso)

\section{Spanish version of the Brief Index of Affective Job Satisfaction (BIAJS)}

1. Disfruto mucho mi trabajo

2. Me gusta mi trabajo más que a la persona promedio

3. En la mayoría de los días, me siento entusiasmado por mi trabajo

4. Me siento muy satisfecho con mi trabajo 
TABLES

Table 1. Means, standard deviations, and correlations among variables

\begin{tabular}{|c|c|c|c|c|c|c|c|c|c|c|c|c|c|c|c|}
\hline Variable & $M$ & $S D$ & 1 & 2 & 3 & 4 & 5 & 6 & 7 & 8 & 9 & 10 & 11 & 12 & 13 \\
\hline 1. Age & 44.40 & 11.76 & - & & & & & & & & & & & & \\
\hline 2. Tenure in the current position & 8.66 & 8.41 & 0.59 & - & & & & & & & & & & & \\
\hline 3. Male & 0.30 & 0.46 & -0.07 & -0.07 & - & & & & & & & & & & \\
\hline 4. Professor & 0.36 & 0.48 & 0.54 & 0.15 & 0.02 & - & & & & & & & & & \\
\hline 5. Postgraduate degree & 0.31 & 0.46 & 0.22 & 0.00 & -0.03 & 0.32 & - & & & & & & & & \\
\hline 6. CSE & 3.66 & 0.51 & 0.17 & 0.10 & 0.06 & 0.18 & 0.02 & 0.80 & & & & & & & \\
\hline 7. Psychological demands & 1.93 & 0.57 & -0.21 & -0.12 & 0.00 & -0.12 & 0.01 & -0.38 & 0.67 & & & & & & \\
\hline 8. Work control & 3.03 & 0.57 & 0.11 & -0.11 & 0.03 & 0.21 & 0.18 & 0.44 & -0.28 & 0.81 & & & & & \\
\hline 9. Social support and leadership & 2.81 & 0.65 & 0.15 & 0.04 & -0.04 & 0.09 & 0.03 & 0.40 & -0.27 & 0.58 & 0.81 & & & & \\
\hline 10. Double presence & 2.14 & 0.72 & -0.24 & -0.24 & -0.24 & -0.08 & 0.09 & -0.19 & 0.22 & -0.29 & -0.21 & 0.60 & & & \\
\hline 11. Esteem & 2.63 & 0.84 & 0.03 & -0.07 & 0.08 & 0.11 & 0.03 & 0.35 & -0.38 & 0.56 & 0.73 & -0.20 & 0.85 & & \\
\hline 12. Job insecurity & 1.33 & 0.90 & -0.16 & -0.03 & 0.06 & -0.23 & -0.03 & -0.35 & 0.33 & -0.36 & -0.35 & 0.22 & -0.37 & 0.75 & \\
\hline 13. Job satisfaction & 3.99 & 0.61 & 0.16 & 0.00 & -0.18 & 0.14 & 0.12 & 0.40 & -0.17 & 0.46 & 0.39 & -0.03 & 0.37 & -0.21 & $\mathbf{0 . 8 3}$ \\
\hline
\end{tabular}

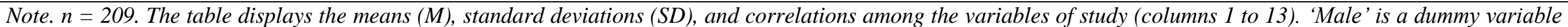

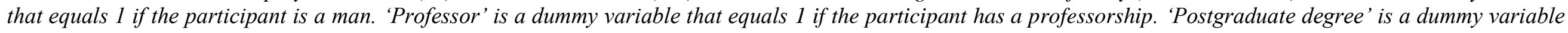

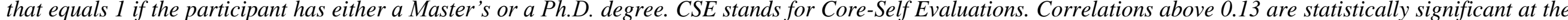

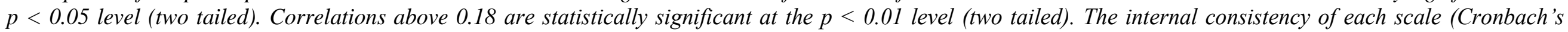
alpha) is reported on the main diagonal in bold. 
Table 2. Hierarchical regression analysis results

\begin{tabular}{|c|c|c|c|c|}
\hline Dependent variable: Job satisfaction & $\begin{array}{l}\text { Model 1: } \\
\text { control } \\
\text { variables }\end{array}$ & $\begin{array}{c}\text { Model 2: } \\
\text { Dispositional } \\
\text { approach }\end{array}$ & $\begin{array}{l}\text { Model 3: } \\
\text { Situational } \\
\text { approach }\end{array}$ & $\begin{array}{l}\text { Model 4: } \\
\text { Interactionist } \\
\text { approach }\end{array}$ \\
\hline Intercept & $\begin{array}{c}3.8015^{* * * *} \\
(0.1788)\end{array}$ & $\begin{array}{c}3.9289 * * * \\
(0.1645)\end{array}$ & $\begin{array}{c}3.7661 * * * \\
(0.1697)\end{array}$ & $\begin{array}{c}3.7923 * * * \\
(0.1704)\end{array}$ \\
\hline \multicolumn{5}{|l|}{ Control variables } \\
\hline Age & $\begin{array}{c}0.0050 \\
(0.0042)\end{array}$ & $\begin{array}{c}0.0028 \\
(0.0038)\end{array}$ & $\begin{array}{c}0.0068 \\
(0.0040)\end{array}$ & $0.0065(0.0039)$ \\
\hline Male & $\begin{array}{c}-0.2382 * * * \\
(0.0905)\end{array}$ & $\begin{array}{c}-0.2715 * * * \\
(0.0813)\end{array}$ & $\begin{array}{c}-0.2265 * * * \\
(0.0841)\end{array}$ & $\begin{array}{c}-0.2542 * * * \\
(0.0799)\end{array}$ \\
\hline Professor & $\begin{array}{c}0.1131 \\
(0.1024)\end{array}$ & $\begin{array}{c}0.0539 \\
(0.0935)\end{array}$ & $\begin{array}{l}-0.0253 \\
(0.0946)\end{array}$ & $-0.0405(0.0915)$ \\
\hline \multicolumn{5}{|l|}{ Dispositional factors } \\
\hline Core self-evaluations & & $\begin{array}{c}0.4679 * * * \\
(0.0907)\end{array}$ & & $\begin{array}{c}0.3026 * * * \\
(0.1043)\end{array}$ \\
\hline \multicolumn{5}{|l|}{ Situational factors } \\
\hline Psychological demands & & & $\begin{array}{c}0.0063 \\
(0.0734)\end{array}$ & $0.0727(0.0780)$ \\
\hline Work control & & & $\begin{array}{c}0.3820 * * * \\
(0.0853)\end{array}$ & $\begin{array}{c}0.3188 * * * \\
(0.0958)\end{array}$ \\
\hline Social support and leadership & & & $\begin{array}{c}0.0605 \\
(0.0895)\end{array}$ & $0.0050(0.1013)$ \\
\hline Double presence & & & $\begin{array}{c}0.0940 \\
(0.0576)\end{array}$ & $0.0899(0.0553)$ \\
\hline Esteem & & & $\begin{array}{l}0.1238^{*} \\
(0.0699)\end{array}$ & $\begin{array}{c}0.1420 * * \\
(0.0651)\end{array}$ \\
\hline Job insecurity & & & $\begin{array}{c}0.0039 \\
(0.0465) \\
\end{array}$ & $0.0267(0.0494)$ \\
\hline VIF & 1.29 & 1.23 & 1.69 & 1.69 \\
\hline Shapiro-Wilk test (z-score) & $0.00[0.0052]$ & $1.73[0.0424]$ & $0.00[0.5007]$ & $0.32[0.3755]$ \\
\hline Breusch-Pagan test (Chi ${ }^{2}$ statistic) & $2.24[0.1347]$ & $8.04[0.0046]$ & $1.24[0.2374]$ & $3.37[0.0663]$ \\
\hline $\mathrm{R}^{2}$ & $0.06^{* * *}$ & $0.21 * * *$ & $0.30 * * *$ & $0.34 * * *$ \\
\hline Adjusted $\mathrm{R}^{2}$ & $0.05^{* * *}$ & $0.19 * * *$ & $0.26^{* * *}$ & $0.31 * * *$ \\
\hline$\Delta$ Adjusted $\mathrm{R}^{2}(\mathrm{M} 1-\mathrm{M} 2-\mathrm{M} 4)$ & \multicolumn{2}{|c|}{$0.14 * * *$} & & $0.12 * * *$ \\
\hline$\Delta$ Adjusted $\mathrm{R}^{2}(\mathrm{M} 1-\mathrm{M} 3-\mathrm{M} 4)$ & & & $0.21 * * *$ & $0.05 * * *$ \\
\hline
\end{tabular}

Note. The table reports the results from the hierarchical regression analyses (HRA). HRA is a model-building technique that shows if a set of variables of interest explain a statistically significant amount of variance in the dependent variable after accounting for all other variables. This is a framework for model comparison, rather than a statistical method, in which predictors are added or removed in multiple steps to see how the $R^{2}$ coefficient varies as we increase the complexity of the models. In model 1 , we only computed the control variables (i.e., age, gender, and hierarchy). In models 2 and 3, we entered the dispositional (i.e., CSE) and situational factors (i.e., psychological demands, work control, social support and leadership, double presence, esteem, and job insecurity), respectively. In model 4, we computed both dispositional and situational factors simultaneously, reflecting an interactionist perspective. 'Male' is a dummy variable that equals 1 if the participant is a man. 'Professor' is a dummy variable that equals 1 if the participant has a professorship. Shapiro-Wilk tests the null hypothesis that the residuals are normally distributed. Breusch-Pagan tests the null hypothesis that the error variances are all equal (homoscedasticity). VIF is the mean of the variance inflation factor, with indices smaller than 10 indicating that the collinearity among the variables of study is not severe. For those models in which some level of heteroskedasticity was detected, we estimated robust standard errors (i.e., models 2 and 4). $\Delta$ Adjusted $R^{2}$ indicates how the adjusted $R^{2}$ coefficient changes when moving from model 1 to model 4 . $* * * p<0.01$, ** $p<0.05, * p<0.10$. Standard errors and robust standard errors are reported in parentheses. $P$-values are reported in brackets. 
Table 3. Regression analysis results based on age group

Dependent variable: Job satisfaction

Group 1 (younger than 40 years)

Group 2 (40 years or older)

Intercept

$$
4.0598 * * *(0.0806)
$$

$4.0776 * * *(0.0726)$

Control variables

Male

$-0.2930 * *(0.1332)$

$-0.2184 * *(0.1052)$

Professor

$-0.2919(0.2100)$

0.0574 (0.0934)

Dispositional factors

Core self-evaluations

$$
0.4522 * * *(0.1561) \quad 0.2629 * *(0.1014)
$$

Situational factors

Psychological demands

$0.0280(0.1261)$

0.0908 (0.0939)

Work control

$0.3753^{* *}(0.1595)$

$0.2841 * * *(0.1003)$

Social support and leadership

$-0.0131(0.1549)$

0.0365 (0.1093)

Double presence

.0559 (.0904)

0.0507 (0.0754)

Esteem

$0.2865^{* *}(0.1209)$

$0.0532(0.0809)$

Job insecurity

0.1114 (0.0904)

$0.0031(0.0538)$

VIF

1.67

1.69

Shapiro-Wilk test (z-score)

$1.29[0.0983]$

1.24 [0.1083]

Breusch-Pagan test ( $\mathrm{Chi}^{2}$ statistic)

$\mathrm{R}^{2}$

$0.07[0.7962]$

$0.67[0.4120]$

Adjusted $\mathrm{R}^{2}$

$0.36 * * *$

$0.29 * * *$

Note. $N$ Group $1=83, N$ Group $2=126$. 'Male' is a dummy variable that equals 1 if the participant is a man. 'Professor' is a dummy variable that equals 1 if the participant has a professorship. Shapiro-Wilk tests the null hypothesis that the residuals are normally distributed. Breusch-Pagan tests the null hypothesis that the error variances are all equal (homoscedasticity). VIF is the mean of the variance inflation factor, with indices smaller than 10 indicating that the collinearity among the variables of study is not severe. $* * * p<0.01$, ** $p<$ $0.05, * p<0.10$. Standard errors are reported in parentheses. $P$-values are reported in brackets. 
FACTORES DISPOSICIONALES Y SITUACIONALES EN EL TRABAJO:

VALIDACIÓN DE ESCALAS Y ANÁLISIS DE SUS INFLUENCIAS SOBRE LA

\section{SATISFACCIÓN LABORAL}

\section{Resumen}

Objetivos - El objetivo de este estudio es examinar las propiedades psicométricas de las versiones en español de la Escala de Autoevaluaciones Esenciales (CSES) y el Índice Breve de Satisfacción Laboral Afectiva (BIAJS) en cuanto a su consistencia interna y estructura factorial y, posteriormente, analizar la influencia relativa de ciertos factores disposicionales (autoevaluaciones esenciales) y situacionales (factores psicosociales) sobre la satisfacción laboral.

Metodología - 209 académicos de una universidad argentina completaron cuestionarios en dos etapas, separadas en el tiempo, para reducir la varianza por uso de método común.

Resultados - Las versiones en español de la CSES y el BIAJS poseen propiedades psicométricas similares a las reportadas previamente en contextos no hispano-parlantes. Los análisis de regresiones múltiples jerárquicas revelan que tanto los factores situacionales como los disposicionales constituyen predictores significativos de la satisfacción laboral.

Implicancias para la investigación - La CSES y el BIAJS son instrumentos válidos y confiables para medir las autoevaluaciones esenciales y la satisfacción laboral en el ámbito latinoamericano. La inclusión simultánea tanto de factores situacionales como disposicionales resulta esencial en futuras investigaciones que examinen la satisfacción laboral.

Implicancias para la práctica - Los directivos deberían evaluar cuidadosamente los rasgos de personalidad de los candidatos en los procesos de selección de personal, así como también las condiciones laborales tendientes a reducir los riesgos psicosociales, ya que ambos factores condicionan la satisfacción laboral. 
Originalidad - Este artículo contribuye a la validación, en el ámbito latinoamericano, de dos escalas de gran utilidad para la Psicología Laboral y el Comportamiento Organizacional. Además, aporta evidencia empírica sobre la influencia relativa de un conjunto comprehensivo de factores situacionales y disposicionales sobre la satisfacción laboral, contribuyendo a la resolución del controversial debate individuo-situación.

Categoría - Artículo de investigación.

Palabras clave: CLADEA 2017, Autoevaluaciones Esenciales, Riesgos Psicosociales, Satisfacción Laboral.

\section{INTRODUCCIÓN}

La satisfacción laboral constituye uno de los fenómenos más estudiados del siglo XX, particularmente en disciplinas como el Comportamiento Organizacional y la Psicología Laboral. En efecto, tal y como señalan Judge, Weiss, Kammeyer-Mueller y Hulin (2017) en su reciente revisión, la satisfacción laboral es mencionada en más del setenta por ciento de los artículos incluidos en PsycINFO y constituye uno de los descriptores más utilizados en el Journal of Applied Psychology, la revista científica de mayor impacto sobre temas ligados a la psicología del trabajo y de las organizaciones. Este interés sostenido por la satisfacción laboral no sólo se ha sustentado en su relevancia para explicar distintas variables vinculadas con la efectividad organizacional, tales como el ausentismo, la rotación de personal, la intención de cambiar de empleo, la ciudadanía organizacional, el compromiso organizacional o el desempeño (e.g., Diestel, Wegge y Schmidt, 2014; Flickinger, Allscher y Fiedler, 2016; Tziner, Waismal-Manor, Vardi y Brodman, 2008; Ziegler, Hagen y Diehl, 2012), sino también en su importancia para la conservación del bienestar del empleado, tanto desde el punto de vista de su salud física como mental (e.g., Grant, Wardle y Steptoe, 2009; Tsaousis, Nikolaou, Serdaris y Judge, 2007). 
Numerosas definiciones de satisfacción laboral han sido propuestas hasta el momento en la literatura, observándose aún argumentos contradictorios en torno a si este complejo constructo involucra exclusivamente procesos emocionales o también cognitivos (ver PujolCols y Dabos, 2018, para una revisión). Así, si bien algunos autores como Weiss (2002) definen la satisfacción laboral como un juicio evaluativo positivo o negativo que el individuo realiza de las diferentes facetas que componen su trabajo (i.e., satisfacción laboral cognitiva), en este artículo se seguirá la definición de Fisher (2000), quien señala que la misma representa una respuesta afectiva o emocional hacia el trabajo como un todo (i.e., satisfacción laboral afectiva). En cuanto a los factores que anteceden o determinan la satisfacción laboral, las perspectivas teóricas más relevantes parecieran encontrarse polarizadas en un enfrentamiento altamente controversial, el cual fue denominado por Kenrick y Funder (1988) debate individuo-situación.

En el primer extremo se encuentran los situacionalistas, quienes enfatizan en la influencia que las variables organizacionales ejercen sobre las actitudes y comportamientos de los empleados (Dierdorff y Morgeson, 2013). Desde esta postura, el diseño del trabajo, entendido como la manera en la que éste es estructurado, organizado, percibido y desempeñado (Grant, Fried y Juillerat, 2010), afecta de manera significativa la satisfacción laboral al establecer un marco de constreñimientos al comportamiento individual y grupal (Bowling, Khazon, Meyer y Burrus, 2015). Al respecto, Unda, Uribe, Jurado, García, Tovalín y Juárez (2016) señalan que los factores psicosociales que, ya sea de manera prescripta o emergente, componen el diseño del trabajo son proclives a exponer a los empleados a mayores o menores riesgos psicosociales, entendidos como aquellos factores laborales que, sea por exceso, defecto o combinación, constituyen una amenaza para la integridad física, social y/o psicológica de los empleados (Meliá, Nogareda, Lahera, Duro, Peiró, Salanova y Gracia, 2006). El estudio de los riesgos psicosociales y sus efectos sobre el bienestar en el 
trabajo ha recibido una gran atención dentro de los estudios situacionalistas, principalmente como resultado de las profundas transformaciones que se han producido en las relaciones de empleo en los últimos años. Específicamente, el llamado Modelo Copsoq-Istas, desarrollado por el Instituto Sindical de Trabajo, Ambiente y Salud de España (Moncada et al., 2004), constituye una de las taxonomías más utilizadas en la investigación iberoamericana sobre riesgos psicosociales, fundamentalmente en virtud de su exhaustividad y parsimonia (PujolCols y Arraigada, 2017; Pujol-Cols y Lazzaro-Salazar, 2018).

En el segundo extremo se encuentran los disposicionalistas, quienes enfatizan en el rol que la personalidad de los individuos ejerce sobre sus actitudes y comportamientos en el trabajo. Así, esta postura sostiene que los sujetos poseen estados mentales inobservables, ligados a los rasgos de su personalidad, que se encuentran dotados de relativa estabilidad y, por lo tanto, predisponen la satisfacción laboral que aquellos son proclives a experimentar en una gran diversidad de contextos organizacionales (Judge, Klinger, Simon y Yang, 2008b; Ones, Dilchert, Viswesvaran y Judge, 2007). En efecto, la literatura disposicional afirma que los individuos son más o menos proclives a experimentar actitudes positivas hacia sus trabajos aún frente a condiciones organizacionales diferentes (Barrick, 2005). Si bien distintas taxonomías de personalidad han sido propuestas hasta el momento en la literatura (e.g., Taxonomía Afectividad Positiva/Afectividad Negativa; Brief, Butcher y Robertson, 1995; Modelo de los Cinco Grandes Rasgos de la Personalidad; Goldberg, 1990), las autoevaluaciones esenciales (CSE por sus siglas en inglés, core self-evaluations; Judge, Locke y Durham, 1997) constituyen el constructo más novedoso que ha demostrado explicar y predecir de manera significativa la satisfacción laboral (e.g., Judge, Heller, and Klinger, 2008a; Judge, Ilies, and Zhang, 2012; Wu and Griffin, 2012). Específicamente, las CSE se refieren a un conjunto de valoraciones esenciales, básicas e inconscientes que los individuos poseen acerca de sí mismos, de otros y de su ambiente (Judge, Erez, Bono y Thoresen, 2003). 
Desde el inicio del debate individuo-situación, tanto el disposicionalismo como el situacionalismo han demostrado su relevancia para explicar la satisfacción laboral (Judge y Zapata, 2015), lo que sugiere que ambas perspectivas teóricas deberían ser contempladas de manera simultánea en aquellas investigaciones que la aborden (Cohrs, Abele y Dette, 2006). A pesar de esto, la mayor parte de la literatura sobre satisfacción laboral pareciera continuar focalizada en examinar los efectos de estos conjuntos de determinantes de manera aislada, siendo verdaderamente limitados los estudios empíricos que la hayan analizado desde una óptica interaccionista (ver Lent y Brown, 2006 y Pujol-Cols y Dabos, 2018 para una discusión detallada sobre este tema). Más aún, la mayor parte de estas investigaciones se han concentrado en un conjunto demasiado estrecho de factores del trabajo, principalmente intrínsecos (e.g., Hackman y Oldham, 1976), ignorando de modo considerable la influencia de otros factores extrínsecos que también resultan relevantes para explicar la satisfacción laboral (Humphrey et al., 2007). Tal y como aseveran Staw y Cohen-Charash (2005), la adopción de un diseño interaccionista, que contemple un conjunto comprehensivo de factores situacionales y disposicionales, no sólo resulta central para mejorar el poder explicativo de los modelos dominantes sobre satisfacción laboral, sino también para subsanar los sesgos de subespecificación en los que muchos de ellos han incurrido como resultado de haber ignorado la influencia de determinantes relevantes. Esta discusión no resulta trivial, pues la subespecificación puede conducir a la sobreestimación de los efectos de las variables explicativas, llevando a interpretaciones equivocadas sobre su magnitud y significatividad, así como sobre su relación con la satisfacción laboral (ver Bernerth y Aguinis, 2016). En este sentido, Staw y Cohen-Charash (2005) advierten que una manera de resolver el debate individuo-situación consiste en desarrollar pruebas competitivas que permitan evaluar la magnitud de los efectos parciales de ambos conjuntos de factores sobre la satisfacción laboral. 
Así, y con el propósito de aportar evidencia empírica que contribuya a la resolución del controversial debate individuo-situación y, en particular, a la literatura interaccionista sobre satisfacción laboral, este artículo se propone, por un lado, examinar las propiedades psicométricas de las versiones en español de la Escala de Autoevaluaciones Esenciales (Core Self-Evaluations Scale, CSES; Judge et al., 2003) y el Índice Breve de Satisfacción Laboral Afectiva (Brief Index of Affective Job Satisfaction, BIAJS; Thompson y Phua, 2012) en términos de consistencia interna y estructura factorial, por primera vez en el contexto latinoamericano, y, por el otro, analizar la influencia relativa de un conjunto de determinantes situacionales y disposicionales sobre la satisfacción laboral.

\section{MARCO TEÓRICO Y DESARROLLO DE HIPÓTESIS}

\section{El enfoque disposicional}

La personalidad, entendida como aquellas características personales de los individuos que determinan formas consistentes de sentir, pensar y comportarse frente a los eventos (Mayer, 2007; Pervin, Cervone y John, 2005), constituye uno de los determinantes de la satisfacción laboral que ha concentrado mayor nivel de interés científico durante las últimas dos décadas (Judge, Klinger, Simon y Yang, 2008b; Ones et al., 2007). En efecto, ha sido el principal objeto de estudio del disposicionalismo, corriente teórica que postula que los individuos poseen estados mentales inobservables, llamados disposiciones, que poseen una elevada estabilidad a través del tiempo (Caspi, Roberts y Shiner, 2005; Dormann, Fay, Zapf y Frese, 2006), al poseer fuertes bases genéticas (Johnson, McGue y Krueger, 2005; Judge et al., 2012) y neuropsicológicas (Pickering y Gray, 1999), que predisponen las actitudes y comportamientos en el trabajo (Judge et al., 2008b). Las Autoevaluaciones Esenciales (CSE por sus siglas en inglés, core self-evaluations), definidas como un conjunto de conclusiones básicas, esenciales e inconscientes que los individuos formulan acerca de sí mismos, de otros 
y de su ambiente (Judge et al., 2003), constituyen la taxonomía de personalidad más novedosa que ha demostrado explicar y predecir de manera significativa la satisfacción laboral (Wu y Griffin, 2012).

Las CSE representan un constructo global, latente y de orden superior, que refleja cuatro rasgos de personalidad fuertemente consolidados en la investigación en Psicología (ver Judge, Locke, Durham y Kluger, 1998). En primer lugar, se encuentra la autoestima, entendida como una medida global de valor que los sujetos se asignan a sí mismos como personas (Harter, 1990). En segundo lugar, está la autoeficacia, que representa el grado de confianza que los individuos poseen acerca de su capacidad para desempeñar las tareas de manera efectiva y alcanzar las metas de manera exitosa (Bandura, 1997). En tercer lugar, se encuentra el locus interno de control, el cual se refiere a la medida en la que los sujetos creen que la mayoría de los eventos que acontecen en sus vidas resultan producto de su propio comportamiento (Rotter, 1966). Al sentir que la mayoría de estos acontecimientos se encuentran bajo su control, este tipo de personas también tiende a asociar los eventos positivos con sus propios méritos y esfuerzos. Finalmente, la estabilidad emocional (o el bajo neuroticismo) representa la tendencia de los individuos a focalizarse en los aspectos más positivos de sí mismos, de otros y de sus vidas (Costa y McCrae, 1988). Los sujetos emocionalmente estables tienden a concentrarse en sus éxitos, más que en sus fracasos, así como en los aspectos más favorables de su trabajo.

La obtención de correlaciones elevadas entre los cuatro rasgos centrales de las CSE en numerosos estudios (e.g., Judge, Erez, Bono y Thoresen, 2002) y resultados de pruebas factoriales que revelaban una estructura subyacente unidimensional (e.g. Judge, Bono y Locke, 2000) motivaron a Judge, Erez, Bono y Thoresen (2003) a desarrollar la Escala de Autoevaluaciones Esenciales (CSES por sus siglas en inglés, Core Self-Evaluation Scale), específicamente diseñada para examinar las CSE como un fenómeno global a través de doce 
reactivos. Es importante destacar que la CSES no sólo se encuentra sustentada teóricamente en una revisión bibliográfica exhaustiva (ver Judge et al., 1997 y Judge et al., 1998), lo que da cuenta de su validez de contenido, sino que también ha exhibido propiedades psicométricas satisfactorias en numerosas investigaciones publicadas en las revistas científicas de mayor impacto de la disciplina (ver Pujol-Cols y Dabos, 2018, para una revisión detallada).

Desde la publicación del artículo seminal de Judge et al. (1997), las CSE han sido estudiadas en diversidad de contextos organizacionales y países (e.g., Stumpp et al., 2010; Dormann et al., 2006; Piccolo et al., 2005; Rode, Judge y Sun, 2012), lo que ha brindado evidencia sobre la universalidad del constructo y la generalizabilidad transcultural de sus efectos sobre la satisfacción laboral. A pesar del interés que la literatura internacional ha mostrado en el objeto de estudio, no fue posible encontrar ninguna investigación que haya examinado la relación entre las CSE y la satisfacción laboral en el ámbito latinoamericano. Sin embargo, la literatura empírica internacional señala al menos tres mecanismos por los que las CSE parecen afectar la satisfacción laboral. Primero, los individuos con CSE más positivas tienden a focalizarse en los aspectos más positivos de su trabajo, a percibirlos de una manera más favorable y a reaccionar más positivamente ante ellos, experimentando como resultado mayor satisfacción laboral (Judge et al., 1998; Cohrs et al., 2006). Segundo, los sujetos con CSE más positivas tienden a seleccionar trabajos más complejos y desafiantes, lo que condiciona las experiencias que son proclives a vivenciar $\mathrm{y}$, consecuentemente, su satisfacción laboral (Kristof-Brown, Zimmerman y Johnson, 2005; Sunal, Sunal y Yasin, 2011; Srivastava, Locke, Judge y Adams, 2010). Finalmente, los individuos con CSE más elevadas tienden a percibir las características de su trabajo como menos estresantes y a experimentar menos stress que aquellos con CSE más negativas (Spector et al., 2000), lo que se encuentra asociado con mayores niveles de satisfacción laboral (Hsieh y Huang, 2017; 
Kammeyer-Mueller et al., 2009). Con sustento en la evidencia presentada en este apartado se propone que:

Hipótesis 1 (H-1): Las CSE se relacionarán de manera positiva y significativa con la satisfacción laboral.

\section{El enfoque situacional}

El situacionalismo tiene su origen en los años posteriores a la Segunda Guerra Mundial y postula que las organizaciones representan situaciones fuertes (Meyer, Dalal y Hermida, 2010), al ejercer una influencia poderosa sobre el comportamiento y las actitudes de los empleados (Humphrey et al., 2007; Morgeson y Humphrey, 2006). Desde esta perspectiva, el diseño del trabajo, entendido como el conjunto de procesos y resultados involucrados en la estructuración, organización, experimentación y desempeño del trabajo (Grant et al., 2011), define o estimula la emergencia de un conjunto de factores psicosociales, los cuales afectan la satisfacción laboral de los empleados al exponerlos a mayores o menores riesgos psicosociales. Estos últimos son entendidos por Meliá et al. (2006) como aquellos factores relacionados con el trabajo que, sea por exceso, defecto o combinación, constituyen una amenaza para la integridad física, social y/o psicológica de los individuos. El Modelo Copsoq-ISTAS, desarrollado por el Instituto Sindical de Trabajo, Ambiente y Salud de España (ISTAS; Moncada, Llorens y Kristensen, 2004), constituye una de las taxonomías más difundidas sobre riesgos psicosociales. En la versión 1.5 de este modelo, Moncada et al. (2004) proponen seis factores del trabajo que representan riesgos para la salud física y psicológica de los empleados, los cuales se describen a continuación.

El primer factor se denomina exigencias psicológicas e involucra tanto las demandas que emergen de la relación entre el volumen de trabajo y el tiempo disponible para realizarlo (i.e., exigencias psicológicas cuantitativas) como las exigencias de no involucrarse en las 
situaciones emocionales implicadas en las relaciones interpersonales laborales (i.e., exigencias psicológicas emocionales). Con respecto a las exigencias psicológicas cuantitativas, existe evidencia que señala que la sensación de sobrecarga de trabajo tiende a conducir a la experimentación de distrés y, como resultado, a insatisfacción laboral (Klassen y Chiu, 2010). Por otro lado, aquellas ocupaciones que involucran mayores exigencias psicológicas emocionales tienden a conducir a la experimentación de disonancia emocional (i.e., la tensión o incongruencia entre las emociones proyectadas y las efectivamente sentidas) y, en consecuencia, a menores niveles de satisfacción laboral (Lewig y Dollard, 2003).

El segundo factor, llamado control sobre el trabajo, es entendido como la medida en la que el trabajo le brinda al empleado oportunidades de autonomía y desarrollo. Los efectos positivos de la autonomía sobre la satisfacción laboral han sido reconocidos durante décadas en la literatura de Management (e.g., Ferguson y Cheek, 2011; Humphrey et al., 2007; Morgeson y Humphrey, 2006). En efecto, y con sustento en la Teoría de la Autodeterminación (Self-determination Theory), la autonomía constituye una necesidad psicológica universal que nutre la motivación intrínseca de los individuos (Gagne y Deci, 2005) y los conduce a experimentar estados positivos, como satisfacción laboral (Humphrey et al., 2007). Por el contrario, resulta esperable que niveles insuficientes de autonomía se encuentren asociados con reducciones en la motivación intrínseca y, en consecuencia, con menores niveles de satisfacción laboral (Skaalvik y Skaalvik, 2014).

El tercer factor, denominado apoyo social y calidad del liderazgo, es definido como la medida en la que el trabajo le posibilita al empleado el desarrollo de vínculos sociales y de colaboración con sus superiores y pares. Al respecto, existe considerable evidencia acerca del rol vital que el apoyo social asume en la satisfacción laboral y el bienestar de los individuos (Häusser, Mojzisch, Niesel y Schulz-Hardt, 2010), particularmente en contextos laborales altamente estresantes (Wrzesniewski, Dutton y Debede, 2003), al mitigar el impacto 
psicosocial de las demandas laborales (Kinman et al., 2011). Puesto que el apoyo social de supervisores y compañeros de trabajo es altamente instrumental, no sólo para el desempeño efectivo (Collins, 2007), sino también para la satisfacción de necesidades humanas fundamentales de orden emocional (e.g., estrategias de ventilación o descarga emocional; Carver, Scheier y Weintraub, 1989) y social (e.g., compañía, pertenencia, reafirmación del valor propio; Heaney e Israel, 2008), resulta esperable que aquellos empleados que perciban una menor presencia de este recurso tiendan a experimentar estados más negativos, como reducciones en su satisfacción laboral (Harris, Winskowski y Engdahl, 2007).

La doble presencia constituye el cuarto factor del modelo, la cual se refiere a la dificultad experimentada por el empleado para balancear las demandas del empleo y las provenientes del ámbito doméstico-familiar. Niveles cada vez más crecientes de competitividad entre las organizaciones han obligado a sus empleados a trabajar bajo condiciones laborales altamente demandantes (Salanova et al., 2005), reduciendo, en consecuencia, el tiempo disponible para balancear las demandas provenientes de la familia y las exigencias derivadas de mantener una carrera exitosa (Goh, Ilies, y Schwind Wilson, 2016). En efecto, la sobrecarga de trabajo tiende a incrementar la probabilidad de conflictos entre el trabajo y la familia, en la medida en que las presiones de rol provenientes de ambos dominios se convierten en mutuamente incompatibles y la participación en un rol dificulta la participación en el otro (Greenhaus y Allen, 2011). Investigaciones previas señalan que el conflicto trabajo-familia se encuentra asociado con reducciones en la satisfacción laboral de los empleados (Ilies, Schwind, Wagner, Johnson, De Rue y Ilgen, 2007).

El quinto factor es denominado por Moncada et al. (2004) inseguridad sobre el futuro y es definido como la preocupación del empleado por una eventual pérdida de empleo o por la posibilidad de cambios no deseados en las condiciones de trabajo fundamentales. Al respecto, existe considerable evidencia que señala que este factor, también a menudo denominado 
inseguridad laboral, constituye un elemento fundamental para explicar la satisfacción laboral (Reisel, Probst, Chia, Maloles y Konig, 2010), en particular en empleados con contratos a tiempo parcial (Waltman, Bergom, Hollenshead, Miller y August, 2012). En efecto, y puesto que el trabajo es altamente instrumental para la satisfacción de un amplio abanico de necesidades básicas y superiores (Weir, 2013), la experimentación de incertidumbre asociada a la permanencia futura en la organización es proclive a conducir a la experimentación de distrés (Mauno, Leskinen y Kinnunen, 2001) y, en consecuencia, a una pérdida de bienestar y satisfacción (Sverke, Hellgren y Naswall, 2002).

El sexto y último factor, llamado estima, se refiere al grado en que el empleado percibe que el respeto, el reconocimiento y el trato que recibe resultan apropiados en comparación con el esfuerzo que invierte en su trabajo. Contribuciones seminales realizadas por Siegrist (1996) ya han advertido que la percepción de una falta de reciprocidad entre el esfuerzo (i.e., la motivación intrínseca para hacer frente a las demandas del trabajo) y el paquete de compensaciones recibidas como contraprestación constituye una fuente fundamental de distrés laboral. Más aún, estudios meta-analíticos posteriores revelan que el grado en que los participantes sienten que recompensas tales como la remuneración, el reconocimiento y las oportunidades de carrera se encuentran distribuidas de manera justa en la organización (i.e., justicia distributiva) juega un rol esencial en su nivel de satisfacción laboral (Cohen-Charash y Spector, 2001). En esta misma línea, Gillespie, Walsh, Winefield y Stough (2001) reportan que la percepción de insuficiencia relativa a las compensaciones y el reconocimiento recibidos constituye una de las fuentes más grandes de distrés ocupacional e insatisfacción laboral. Con sustento en las ideas presentadas en este acápite se propone que:

Hipótesis 2 (H-2): Los factores psicosociales que representan recursos laborales (i.e., autonomía, estima, apoyo social y calidad del liderazgo) se relacionarán de manera positiva y significativa con la satisfacción laboral, mientras que aquellos que representan demandas 
laborales (i.e., exigencias psicológicas, doble presencia, inseguridad sobre el futuro) se relacionarán de manera negativa y significativa con la satisfacción laboral.

\section{El enfoque interaccionista}

Funder et al. (2012) advierten que el debate individuo-situación se construye sobre el postulado equivocado de que existe una dicotomía entre la persona y la situación, argumentando que las actitudes y el comportamiento humano resultan producto de la influencia simultánea de ambos factores. En este sentido, si bien es cierto que las personas tienden a ajustar sus actitudes y comportamientos a las influencias del diseño del trabajo, al mismo tiempo, mantienen su individualidad. Sin embargo, a pesar de que los argumentos en favor del empleo de una perspectiva interaccionista se han incrementado sustancialmente en los últimos años (Judge y Zapata, 2015), no sólo resultan verdaderamente limitadas las investigaciones empíricas que contemplan de manera simultánea los efectos de la personalidad y los factores situacionales del trabajo sobre la satisfacción laboral (Cohrs, Abele y Dette, 2006; Funder et al., 2012; Lent y Brown, 2006), sino que también han arribado a resultados inconsistentes o contradictorios (Chang, Ferris, Johnson, Rosen y Tang, 2012; Hsieh y Huang, 2017). A modo de ejemplo, Dormann et al. (2006) reportan que el $62 \%$ de la variabilidad observada en la satisfacción laboral pareciera deberse a factores vinculados con la situación, mientras que sólo el 24,25\% pareciera estar explicado por otro conjunto de factores de naturaleza más estable, como las disposiciones. Por otro lado, Thomas, Buboltz y Winkelspecht (2004) señalan que ninguno de los rasgos que componen el Modelo de Tipos de Personalidad de Myers-Briggs (Myers, McCaulley, Quenk y Hammer, 1998) logran explicar de manera estadísticamente significativa la satisfacción laboral, una vez que las características intrínsecas del trabajo (i.e., autonomía, variedad) son contempladas en los análisis de regresiones jerárquicas. Más recientemente, un estudio conducido por Cohrs et al. (2006) 
revela que sólo dos variables situacionales, la autonomía y el liderazgo participativo, y una disposicional, la autoeficacia ocupacional, explican significativamente la satisfacción laboral cuando la totalidad de las variables incluidas en la investigación son tenidas en consideración. Más recientemente, Nguyen y Borteyrou (2016) reportan que las disposiciones explican positiva y significativamente la satisfacción laboral, incluso luego de que sus efectos sean controlados por la influencia de variables situacionales como las demandas del trabajo y la autonomía.

Existen distintas razones que podrían explicar las inconsistencias discutidas en el párrafo precedente. En primer lugar, la mayoría de las investigaciones interaccionistas han privilegiado, ya sea más o menos sutilmente, uno de los conjuntos de determinantes en detrimento del otro (Haney y Zimbardo, 2009). En segundo lugar, han evadido efectuar pruebas competitivas que permitan examinar y comparar la influencia relativa, así como el poder explicativo, de los determinantes disposicionales y situacionales sobre la satisfacción laboral (Staw y Cohen-Charash, 2005). En tercer lugar, se han focalizado excesivamente en los factores situacionales intrínsecos (i.e., aquellos que se refieren a las características de la tarea), ignorando de modo considerable los efectos de otros factores de naturaleza extrínseca (i.e., aquellos asociados al contexto físico, organizacional y social en el que las tareas son desempeñadas) que también han demostrado ser relevantes para explicar la satisfacción laboral (Humphrey et al., 2007; Hogan, 2009). En cuarto lugar, han recurrido al empleo de escalas ad-hoc para la medición de los factores situacionales del trabajo, en lugar de emplear taxonomías genéricas que faciliten la comparación de los hallazgos entre contextos organizacionales, ocupaciones o países (Buss, 2009). No obstante, y con sustento en la evidencia presentada en este apartado, así como también en los dos anteriores, se propone que: 
Hipótesis 3 (H-3). Tanto los factores disposicionales como los situacionales explicarán varianza incremental sobre la satisfacción laboral.

\section{MÉTODO}

\section{Participantes}

Se contó con la participación voluntaria de 209 académicos de una facultad de una universidad pública argentina. La edad de los participantes osciló entre 23 y 70 años, con una media de 44,40 y una desviación estándar de 11,76. El 69,86\% de los participantes fueron mujeres. Con respecto a la jerarquía, el 36,36\% eran Profesores, el 19,62\% Jefes de Trabajos Prácticos y el 44,02\% Auxiliares. En cuanto a la dedicación horaria, el 24,88\% contaba con un contrato de tiempo completo. La antigüedad de los participantes osciló entre 1 y 45 años, con una media de 17,49 y una desviación estándar de 10,51. La antigüedad en el cargo actual varió entre 1 y 30 años, con una media de 8,66 y una desviación estándar de 8,41. Con respecto a la formación, el 69,38\% de los participantes tenían título de pre-grado, el 19\% título de Máster y $12 \%$ restante título de Doctor.

\section{Procedimiento}

Una vez que las máximas autoridades académicas de la facultad autorizaron la realización del estudio, se envió un cuestionario virtual, desarrollado a través de la herramienta de uso gratuito Google Drive ${ }^{\circledR}$, a un total de 414 académicos. El cuestionario se encontró precedido por una descripción de los objetivos de la investigación y un formulario de consentimiento informado. También incluyó una dirección de correo electrónico a la que el participante podía comunicarse en caso de poseer una inquietud, consulta o sugerencia. Sólo se dio acceso al cuestionario digital a quienes hubieran autorizado de manera expresa su participación mediante la aceptación del formulario de consentimiento informado (a tales 
efectos, se incorporó un botón con la leyenda "acepto participar en esta investigación"). Si bien las invitaciones fueron enviadas desde una dirección institucional de la facultad, se les aclaró a los participantes que cualquier información que permitiera identificarlos sería estrictamente confidencial y que sólo los investigadores principales de este estudio tendrían acceso a los datos recolectados (ver Declaración de Helsinki de 1964 y Declaración de Singapur de 2010). Siguiendo el procedimiento recomendado por Judge et al. (2005) para reducir el sesgo de método común, el relevamiento se realizó en dos etapas. En la primera, los participantes fueron invitados a responder un cuestionario sobre sus CSE. En la segunda, y con dos semanas de diferencia, se los invitó a responder el de satisfacción laboral y el de riesgos psicosociales. Un total de 209 individuos completaron voluntariamente los cuestionarios en ambas etapas durante un período de cinco meses (tasa de respuesta $=$ $50,48 \%)$

\section{Variables e instrumentos}

Las Autoevaluaciones Esenciales fueron examinadas utilizando la Core SelfEvaluations Scale (CSES; Judge et al., 2003). La misma se compone por doce reactivos (ver Anexo) y una escala de frecuencia de cinco niveles $(1=$ totalmente en desacuerdo, $5=$ totalmente de acuerdo). Los puntajes individuales de los doce ítems fueron promediados para formar un solo puntaje de CSE.

La satisfacción laboral fue medida de manera global a través del Brief Index of Affective Job Satisfaction (BIAJS; Thompson y Phua, 2012). El mismo se compone por cuatro reactivos (ver Anexo) y una escala de cinco niveles $(1=$ totalmente en desacuerdo, $5=$ totalmente de acuerdo). Los puntajes individuales de los cuatro ítems fueron promediados para formar un solo puntaje de satisfacción laboral global. 
Para examinar los factores psicosociales se utilizó la versión reducida del Cuestionario de Evaluación de Riesgos Psicosociales en el Trabajo Copsoq-ISTAS 21 (Moncada et al, 2004), versión 1.5. El mismo se encuentra compuesto por un total de 38 reactivos e incluye una escala de respuesta de cinco puntos, con valores entre 0 y 4 . Este instrumento ha sido específicamente diseñado para identificar, medir y valorar la percepción de exposición a seis grandes grupos de factores del trabajo que representan riesgos para la salud psicosocial: exigencias psicológicas (6 ítems), control sobre el trabajo (10 ítems), apoyo social y calidad del liderazgo (10 ítems), doble presencia (4 ítems), estima (4 ítems) e inseguridad sobre el futuro (4 ítems). El puntaje total para cada factor de riesgo fue calculado como el promedio de los puntajes asignados a cada uno de sus reactivos.

\section{Traducción y adaptación de las escalas}

Puesto que la CSES y el BIAJS fueron desarrollados originalmente en inglés, y con la intención emplearlos en el contexto argentino, ambos instrumentos fueron traducidos directamente de estas versiones al idioma español, siguiendo una versión simplificada del procedimiento de Hambleton, Merenda y Spielberger (2006). Así, y teniendo en consideración que los reactivos del instrumento adaptado deben ser capaces de captar el significado lingüístico de aquellos incluidos en la versión original (Muñiz, Elosua y Hambleton, 2013), se recurrió a la asistencia externa de un traductor con formación doctoral y postdoctoral en Lingüística, formación universitaria en el estudio y la enseñanza del inglés y numerosas publicaciones científicas sobre interculturalidad (ver sección Agradecimientos para una descripción más detallada de su colaboración). Ambos investigadores bilingües y el asesor tradujeron de manera separada el instrumento del inglés (e.g., "I am confident I get the success I deserve in life") al español (e.g., "me siento confiado en que obtengo el éxito que merezco en la vida") y, nuevamente, del español al inglés (back translation, ver Brislin, 
1980). Estas tres traducciones y retro-traducciones independientes fueron luego comparadas, resolviéndose las diferencias mediante el acuerdo mutuo. Más que pretender una traducción literal, se buscó que los reactivos de las escalas traducidas conservaran su sentido original (i.e., equivalencia cultural y lingüística) en el contexto argentino (Behling y Law, 2000; Muñiz et al., 2013). Las versiones en español de ambas escalas pueden ser consultadas en el Anexo de este artículo.

\section{Análisis de datos}

La confiabilidad de la CSES y el BIAJS fue analizada en términos de su consistencia interna, por medio del cálculo del coeficiente Alfa de Cronbach. En cuanto a la estructura factorial de ambas escalas, se realizó un análisis factorial confirmatorio (AFC) en dos etapas. En la primera, se verificó el cumplimiento de los supuestos mínimos para la aplicación del modelo (Hair, Anderson, Tatham y Black, 1995), por medio del cálculo de la medida de adecuación muestral de Kaiser-Meyer-Olkin (KMO) y de la prueba de la esfericidad de Bartlett. En la segunda, se examinó la estructura factorial de la CSES y el BIAJS mediante un análisis factorial confirmatorio (AFC) realizado con la técnica de ecuaciones estructurales. El método de estimación fue el de máxima verosimilitud, por ser el más frecuentemente empleado en la mayoría de los análisis factoriales confirmatorios (Brown, 2006). Los datos fueron procesados en IBM SPSS AMOS® (versión 22).

Para analizar la influencia relativa de los factores situacionales (factores psicosociales) y disposicionales (CSE) sobre la satisfacción laboral, se realizaron análisis de regresiones múltiples jerárquicas (Aiken, West y Reno, 1991). De manera previa, se verificó que los datos recolectados dieran cumplimiento a los supuestos mínimos para la aplicación de las herramientas mencionadas, i.e. normalidad (a través de la prueba $\mathrm{W}$ de Shapiro-Wilk), homocedasticidad (a través de la prueba de Breusch-Pagan) y no colinealidad perfecta (a 
través del cálculo del Factor de Inflación de Varianza, VIF). Adicionalmente, se examinó la presencia de varianza de método común a través de la prueba de un factor de Harman. Los datos fueron procesados en IBM SPSS® (versión 24).

\section{RESULTADOS}

\section{Análisis descriptivo y propiedades psicométricas de las escalas}

Las medias, desviaciones estándar y correlaciones entre las variables del estudio son presentadas en la Tabla 1. Como puede observarse, las CSE exhiben una correlación positiva y significativa con la satisfacción laboral, indicando que CSE más elevadas se hallan asociadas con niveles mayores de satisfacción laboral. Además, las CSE presentan correlaciones positivas y significativas con los tres factores psicosociales que representan recursos laborales (i.e., control sobre el trabajo, apoyo social y liderazgo y estima) y negativas con los tres factores que representan demandas laborales (i.e., exigencias psicológicas, doble presencia e inseguridad sobre el futuro), indicando que aquellos individuos con CSE más positivas tienden a percibir un menor nivel de exposición a riesgos psicosociales. Por otro lado, los factores psicosociales que representan recursos laborales exhiben correlaciones positivas y significativas con la satisfacción laboral, existiendo una relación inversa en el caso de los factores que representan demandas laborales.

\section{INSERTE TABLA 1 AQUÍ}

Como puede observarse en la diagonal principal de la Tabla 1, la versión en español de la CSES muestra una consistencia interna satisfactoria $(\alpha=0,80)$, la cual no sólo resulta superior al estándar de 0,70 sugerido por Nunnally y Bernstein (1994), sino que también es 
similar a la reportada en investigaciones previas realizadas en contextos laborales no hispanoparlantes (e.g., Judge et al., 2003; Stumpp et al., 2010). En cuanto a su estructura factorial, estudios previos (e.g., Judge et al., 2003) señalan que los doce reactivos de la CSES tienden a saturar en un único factor latente. Con el propósito de contrastar la unidimensionalidad de la CSES, se realizó un análisis factorial confirmatorio en AMOS® (versión 22), a través del método de ecuaciones estructurales. En la evaluación del modelo, se siguieron las recomendaciones de Byrne (2001) de reportar y comparar distintos índices de ajuste, tales como el estadístico chi-cuadrado $\left(\chi^{2}\right)$, el comparative fit index (CFI), el goodness of fit index (GFI) y el root mean square error of approximation (RMSEA). Valores de CFI y GFI iguales o superiores a 0,90 y de RMSEA de hasta 0,08 indican un buen ajuste (Byrne, 2001). Los resultados del AFC revelan que el modelo unidimensional brinda un ajuste aceptable a los datos $\left(\chi^{2}=112,81, \mathrm{gl}=54, \mathrm{p}<0,01 ; \chi^{2} / \mathrm{df}=2,09 ; \mathrm{CFI}=0,88, \mathrm{GFI}=0,92 ; \mathrm{RMSEA}=0,07\right)$, siendo los índices obtenidos similares a los reportados por Judge et al. (2003) en seis muestras independientes de trabajadores anglosajones (CFI entre 0,87 y 0,95; GFI entre 0,88 y 0,94 y RMSEA entre 0,05 y 0,08). Hallazgos similares se obtuvieron para la versión en español del BIAJS. En efecto, el instrumento también muestra una consistencia interna satisfactoria $(\alpha=$ 0,83), muy similar a la reportada por Thompson y Phua (2012) para el índice americano $(\alpha=$ 0,85). En cuanto a su estructura factorial, dado que la satisfacción laboral afectiva representa un constructo unidimensional, que refleja una respuesta emocional del empleado hacia el trabajo como un todo (Fisher, 2000), se hipotetizó un modelo en el que los cuatro reactivos del BIAJS debían saturar en un único factor latente. Así, y de manera consistente con lo reportado previamente en contextos anglosajones, los resultados del AFC revelan que el modelo unidimensional brinda un ajuste satisfactorio a los datos $\left(\chi^{2}=12,11, \mathrm{gl}=2, \mathrm{p}<0,01\right.$, $\mathrm{CFI}=0,97, \mathrm{GFI}=0,97, \mathrm{RFI}=0,90, \mathrm{TLI}=0,91)$. 


\section{Varianza de método común}

Dado que la percepción de exposición a los seis factores psicosociales y la satisfacción laboral fueron examinadas en el mismo momento temporal, situación que puede conducir al denominado sesgo de método común, se decidió realizar la prueba de un factor de Harman (Harman's one factor test). Para ello, la totalidad de las variables del estudio fueron simultáneamente introducidas en un análisis factorial exploratorio. Los resultados revelaron que el factor único sólo explicó el 26,01\% de la varianza total, porcentaje que es inferior al nivel crítico del 50\% señalado por Podsakoff, McKenzie, Lee y Podsakoff (2003). Esto indica que el sesgo de método común no afectó de manera significativa los resultados del estudio.

\section{Efectos de los determinantes disposicionales y situacionales sobre la satisfacción laboral}

Con el propósito de comparar la influencia relativa de las CSE y de la percepción de exposición a los seis factores psicosociales sobre la satisfacción laboral, se realizó un análisis de regresiones múltiples jerárquicas. De manera previa, se verificó que los datos dieran cumplimiento a los supuestos de normalidad, homocedasticidad y no multicolinealidad perfecta (ver Tabla 2).

Siguiendo el procedimiento de Aiken y West (1991), el análisis de regresiones múltiples jerárquicas se realizó en tres etapas: (a) las variables de control fueron ingresadas en el Modelo 1; (b) los determinantes disposicionales (i.e., las CSE) y situacionales (i.e., exigencias psicológicas, control sobre el trabajo, apoyo social y liderazgo, doble presencia, estima e inseguridad sobre el futuro) fueron ingresados de manera separada en los Modelos 2 y 3, reflejando, respectivamente, una perspectiva disposicional y una situacional; y (c) los determinantes disposicionales y situacionales fueron ingresados de manera conjunta en el Modelo 4, reflejando una perspectiva interaccionista (ver Tabla 2). 
En cuanto al Modelo 1, se introdujeron como variables de control aquellas que hubieran verificado correlaciones estadísticamente significativas con la satisfacción laboral (ver Tabla 1), siendo estas: (a) la edad del participante, (b) el género (grupo base $=$ mujeres) y (c) la jerarquía del cargo (grupo base $=$ docentes $\sin$ cargo de profesor). Tal y como puede observarse en la Tabla 2, el género constituyó la única variable de control estadísticamente significativa, observándose que la satisfacción laboral parece ser, en promedio, inferior en los hombres que en las mujeres.

En el Modelo 2 (el cual explica el 21\% de la variabilidad observada en la satisfacción laboral, ver los coeficientes $\mathrm{R}^{2}$ en la Tabla 2), las CSE fueron introducidas únicamente en conjunto con las variables de control (reflejando una perspectiva disposicional), sin controlar sus efectos por la influencia de los factores situacionales. Los resultados de este modelo revelan que los determinantes disposicionales explican de manera incremental (ver las variaciones en el $\mathrm{R}^{2}$ ajustado indicadas en la Tabla 2) el $14 \%$ de la variabilidad de la satisfacción laboral (i.e., las CSE tienen un efecto positivo sobre la satisfacción laboral de los participantes, incluso luego de considerar las variables de control), brindando soporte a H-1. En el Modelo 3 (el cual explica el 30\% de la variabilidad observada en la satisfacción laboral, ver el coeficiente $\mathrm{R}^{2}$ en la Tabla 2), los seis factores psicosociales fueron ingresados únicamente en conjunto con las variables de control (reflejando una perspectiva situacional), obteniéndose que explican de manera incremental (ver las variaciones en el $\mathrm{R}^{2}$ indicadas en la Tabla 2) el $21 \%$ de la variabilidad de la satisfacción laboral, incluso luego de controlar sus efectos por la incidencia de las variables de control. Estos resultados brindan soporte parcial a $\mathrm{H}-2$.

En el Modelo 4 (el cual explica el 34\% de la variabilidad observada en la satisfacción laboral; ver los coeficientes $\mathrm{R}^{2}$ en la Tabla 2), tanto las CSE como los factores psicosociales fueron computados de manera simultánea con el propósito de examinar sus efectos parciales 
sobre la satisfacción laboral (reflejando una perspectiva interaccionista). Como puede observarse en la Tabla 2, las CSE permanecen estadísticamente significativas, incluso luego de que los factores situacionales y las variables de control hayan sido introducidos en las regresiones, lo que brinda evidencia sobre su capacidad explicativa incremental sobre la satisfacción laboral y, por lo tanto, da soporte a H-3. En cuanto a los factores psicosociales, sólo dos de sus dimensiones (i.e., el control sobre el trabajo y la estima) verifican efectos parciales estadísticamente significativos, lo que brinda soporte parcial a H-3. Asimismo, se observa que este modelo integrador reporta un acrecentamiento estadísticamente significativo en su capacidad explicativa sobre la satisfacción $\left(\mathrm{R}^{2}\right.$ ajustado $=0,31, \mathrm{p}<0,01 ; \Delta \mathrm{R}^{2}$ ajustado modelo 2-modelo4 $=0,12, \mathrm{p}<0,01 ; \Delta \mathrm{R}^{2}$ ajustado modelo 3-modelo4 $=0,05, \mathrm{p}<0,01$ ), lo que brinda soporte empírico a la relevancia de emplear una perspectiva interaccionista.

INSERTE TABLA 2 AQUÍ

Con el propósito de examinar si los resultados del modelo 4 podrían variar según el grupo etario, se procedió a separar la muestra en dos grupos independientes (i.e., participantes con menos o más de 40 años, ver Tabla 3). Los resultados fueron bastante similares en ambos grupos, aunque la estima sólo resultó estadísticamente significativa en el grupo 1. Por otro lado, los efectos de las CSEs sobre la satisfacción laboral fueron más débiles en el grupo 1 que en el grupo 2.

INSERTE TABLA 3 AQUÍ 


\section{DISCUSIÓN Y CONCLUSIONES}

Si bien treinta años han transcurrido desde que Kenrick y Funder (1988) emplearon el término debate individuo-situación para referirse al enfrentamiento entre el disposicionalismo y el situacionalismo, dicho período parece no haber sido suficiente para resolver completamente las críticas de los defensores de cada postura (Judge y Zapata, 2015). Al enfoque disposicional no sólo se le cuestiona la especificación de sus modelos, argumentándose que la mayoría de estas investigaciones no han controlado adecuadamente los efectos de la personalidad por la incidencia de factores situacionales importantes (Funder et al., 2012), sino también su relevancia práctica, aseverándose que frente a la presencia de situaciones organizacionales fuertes es probable que los efectos de la personalidad sobre la satisfacción laboral resulten poco significativos (Cooper y Withey, 2009). Al enfoque situacional se le critica su focalización excesiva en los aspectos intrínsecos del trabajo (Humphrey et al., 2007) y el empleo de taxonomías arbitrarias y poco comparables (Buss, 2009; Reis, 2008), además de haber evadido el tratamiento de la personalidad en sus modelos (Staw y Cohen-Charash, 2005). Una de las contribuciones de este artículo consistió, entonces, en el análisis de la influencia relativa de un conjunto de factores disposicionales y situacionales sobre la satisfacción laboral. Los factores situacionales fueron examinados por medio de un conjunto de factores psicosociales tanto intrínsecos como extrínsecos (i.e., las exigencias psicológicas, el control sobre el trabajo, el apoyo social y liderazgo, la doble presencia, la estima y la inseguridad sobre el futuro) y los factores disposicionales por medio de las CSE.

En primer lugar, las CSE permanecieron estadísticamente significativas en todos los modelos, incluso luego de que los factores situacionales y los controles fueran contemplados en las regresiones. Este hallazgo brindó soporte a H-1 y H-3 y resultó consistente con otras investigaciones previas que sostienen la existencia de una fuente disposicional de satisfacción 
laboral (e.g., Stumpp et al., 2010; Dormann et al., 2006; Wu y Griffin, 2012). Existen distintos motivos por los que se espera que las CSE se relacionen positiva y significativamente con la satisfacción laboral. Al respecto, Judge et al. (1998) argumentan que "las CSE constituyen la base desde la cual ocurre la evaluación de las situaciones específicas" (pp. 31, traducción de los autores), lo que significa que aquellos individuos con CSE más elevadas tienden a poseer los recursos personales que les permiten ver y evaluar los diferentes dominios de sus vidas, incluido el laboral, de una manera más positiva. En efecto, aquellos sujetos con CSE más positivas tienden a sentirse más satisfechos con sus trabajos puesto que: (a) poseen mayor autoestima y, en consecuencia, se ven a sí mismos como merecedores de mayor felicidad; (b) tienen mayor autoeficacia, lo que significa que poseen una elevada confianza en sus capacidades para superar los aspectos más desafiantes y difíciles de su trabajo; (c) tienen un locus más interno de control y, como resultado, tienden a atribuir los resultados más positivos de sus trabajos a sus propios méritos y esfuerzos; (d) poseen niveles menores de neuroticismo, lo que significa que son menos proclives a focalizarse en sus fracasos, así como en los aspectos más negativos de su trabajo (Srivastava et al., 2010).

En segundo lugar, el control sobre el trabajo y la estima constituyeron los únicos predictores situacionales significativos de la satisfacción laboral, siendo el primero de los factores el que exhibió el efecto parcial de mayor magnitud. Si bien la autonomía y la estima ya han sido señaladas como predictores relevantes de la satisfacción laboral en numerosas investigaciones previas realizadas desde un abordaje situacional (e.g., Dierdorff y Morgeson, 2013; Edwards et al., 2000; Morgeson y Humphrey, 2006), el presente estudio demostró que ambos determinantes poseen un poder predictivo incremental frente a los determinantes disposicionales y las variables de control, lo que brindó soporte parcial a H-2 y H-3. En efecto, cuando los empleados sienten que tienen control sobre su trabajo o que las recompensas que reciben (sean materiales o simbólicas) son justas en comparación con los 
esfuerzos que realizan, tienden a experimentar mayor satisfacción laboral, principalmente como resultado de un acrecentamiento en su motivación intrínseca y una mayor vinculación con la tarea (Gagné y Deci, 2005; Humphrey et al., 2007; Cohen Charash y Spector, 2001; Harris et al., 2007).

Cabe preguntarse por qué la doble presencia y las exigencias psicológicas, factores situacionales que registraron la prevalencia más elevada en la muestra de este estudio, no constituyeron predictores significativos de la satisfacción laboral. Una explicación tentativa podría encontrarse en el contexto ocupacional en el que se realizó esta investigación. Por ejemplo, los participantes podrían haber sentido que las elevadas exigencias psicológicas que enfrentan durante el ejercicio de su rol (e.g., dictado de clases de grado y de postgrado, corrección de exámenes, supervisión y corrección de trabajos académicos, participación en eventos institucionales, formación y actualización permanente, etc.), así como la doble presencia que suele derivarse de aquellas, constituyen una parte inherente de su profesión, ejerciendo ambos factores un papel menos relevante en su satisfacción laboral. En cambio, la estima y la autonomía podrían haber sido vistas por los participantes como variables sobre las que las universidades pueden ejercer un mayor dominio para mejorar sus condiciones de trabajo. En efecto, los hallazgos de esta investigación señalaron que el grado en que los participantes perciben que son capaces de influir de manera significativa en la planificación, diseño e implementación de su trabajo, así como la medida en la que sienten que son recompensados material y simbólicamente de manera adecuada por los esfuerzos que invierten en el ejercicio de su rol, realmente hacen la diferencia en su satisfacción laboral. En este sentido, estas proposiciones resultan consistentes con lo señalado en algunas investigaciones previas realizadas en el contexto de las universidades argentinas, las cuales indican que los bajos salarios, las débiles oportunidades de desarrollo de carrera y el escaso reconocimiento constituyen factores centrales que explican la pérdida de bienestar en los 
académicos argentinos (e.g., Fernández Lamarra y Marquina, 2013; García de Fanelli y Moguillansky, 2014; Pujol-Cols y Lazzaro-Salazar, 2018; Pujol-Cols y Arraigada, 2017).

En tercer lugar, los resultados de esta investigación demostraron que, cuando los factores situacionales y disposicionales son considerados de manera conjunta, el poder explicativo de ambos sobre la satisfacción laboral se incrementa significativamente, sugiriendo que ambas categorías de factores resultan relevantes para explicarla y que, en consecuencia, deberían ser contempladas en futuras investigaciones que la aborden. En este sentido, los hallazgos de esta investigación se encuentran en línea con lo reportado en otros trabajos previos (si bien estos han sido conducidos desde una lógica fundamentalmente disposicional o situacional) y, a la vez, brindan soporte empírico a las proposiciones teóricas pronunciadas en defensa de un abordaje interaccionista de la satisfacción laboral (e.g., Funder et al., 2012).

La segunda contribución de este artículo consistió en la traducción de la CSES y el BIAJS al idioma español (ver Anexo) y, posteriormente, en el examen de sus propiedades psicométricas en el contexto argentino. En cuanto a la confiabilidad de la versión en español de la CSES, la misma mostró una consistencia interna satisfactoria, similar a la reportada en investigaciones previas realizadas en contextos no hispano-parlantes (e.g., Stumpp et al., 2010; Judge et al., 2003). En cuanto a su estructura factorial, los resultados del análisis factorial confirmatorio brindaron soporte al modelo unidimensional sugerido previamente en la literatura (e.g., Dormann et al., 2006; Judge et al., 2003; Piccolo et al., 2005). Por otro lado, en esta investigación se observaron correlaciones positivas y estadísticamente significativas entre las CSE y la satisfacción laboral, lo cual se encuentra en línea con lo reportado en investigaciones anteriores (e.g., Wu y Griffin, 2012) y brinda evidencia sobre la validez predictiva de la CSES. Con respecto al BIAJS, los resultados revelaron que su versión en español también posee una consistencia interna satisfactoria, la cual fue muy similar a la 
reportada por Thompson y Phua (2012) para el índice anglosajón. A su vez, sus cuatro reactivos reflejaron una estructura unidimensional, lo que resulta consistente con las proposiciones de Fisher acerca de la satisfacción laboral afectiva (2000).

\section{Implicancias para la práctica profesional}

Los hallazgos de esta investigación tienen fuertes implicancias para la práctica profesional. Por un lado, resulta esencial que los directivos efectúen una apropiada evaluación de la personalidad de los candidatos durante los procesos de selección de personal, dado que la misma tiende a condicionar la satisfacción laboral que son proclives a experimentar. Por el otro, los resultados de este estudio también señalan que una selección efectiva no es suficiente para lograr niveles elevados de satisfacción laboral, resultando fundamental que las organizaciones introduzcan modificaciones en el diseño del trabajo con el propósito de reducir su impacto psicosocial sobre los empleados y así evitar declives no deseados en su satisfacción laboral. En particular, los resultados de esta investigación señalan que los directivos deberían poner especial atención en los niveles de autonomía y estima que brindan a sus empleados, dado que ambos constituyen determinantes centrales de la satisfacción laboral.

\section{Limitaciones y futuras líneas de investigación}

Al margen de las contribuciones que este estudio realiza, se considera necesario reconocer algunas de sus limitaciones. Primero, esta investigación se sustentó en datos de corte trasversal, lo que impide a los autores postular relaciones de causa-efecto entre las variables examinadas. Futuras investigaciones deberían emplear diseños longitudinales, lo que permitiría explorar con mayor robustez la direccionalidad de las relaciones propuestas en este artículo (ver Wu y Griffin, 2012). Segundo, la muestra empleada para conducir esta investigación estuvo conformada por trabajadores calificados, que suelen gozar de niveles 
relativamente altos de autonomía y flexibilidad laboral, lo que compromete en cierto sentido la generalizabilidad de los resultados a otros contextos organizacionales o profesiones. Futuras investigaciones deberían recurrir a muestras más heterogéneas de empleados, que se hallen expuestos a un rango más amplio de condiciones laborales. Tercero, y a pesar de que esta investigación fue cauta en considerar la incidencia tanto de factores situacionales intrínsecos como extrínsecos, podría argumentarse que existen otros factores situacionales del trabajo (e.g., disonancia emocional, ver Lewig y Dollard, 2003; políticas de diferenciación laboral, ver Rivero y Dabos, 2017) que también podrían resultar relevantes para explicar la satisfacción laboral y que no fueron considerados en los análisis empíricos. Futuras investigaciones podrían incorporar otros factores situacionales relevantes o descomponer las taxonomías utilizadas en categorías más específicas. Además, futuros estudios también podrían incorporar medidas objetivas de factores situacionales, por ejemplo, realizando un análisis sistemático de los puestos de trabajo. Cuarto, los efectos disposicionales y situacionales examinados en este estudio fueron principalmente directos. Futuras investigaciones deberían explorar la posible influencia mediadora o moderadora de otros factores relevantes en las relaciones propuestas en este artículo. Finalmente, las propiedades psicométricas de la CSES y el BIAJS fueron examinadas en esta investigación únicamente en términos de su consistencia interna y estructura factorial. Futuros estudios deberían analizar otros indicadores de validez, tales como la validez convergente, la validez discriminante, la estabilidad y la equivalencia poblacional, empleando para ello varias muestras independientes de empleados de diferentes sectores ocupacionales.

\section{Conclusiones}

Los hallazgos de esta investigación indican que las versiones en español de la CSES y el BIAJS poseen propiedades psicométricas satisfactorias, en términos de confiabilidad y 
dimensionalidad, siendo adecuada su utilización en el contexto latinoamericano. Además, los resultados también revelan que las percepciones de los empleados sobre cuán favorables o desfavorables son sus condiciones laborales (especialmente en lo que refiere a la autonomía y la estima) son relevantes para explicar su satisfacción laboral, independientemente de los efectos de la personalidad. Al mismo tiempo, los hallazgos de este estudio brindan evidencia sobre el rol que los factores disposicionales de los empleados, dentro de los cuales se incluye su personalidad, asumen en su satisfacción laboral, de modo que éstos mantengan una actitud positiva hacia su trabajo, aún frente a la presencia de factores de riesgo psicosocial.

\section{Agradecimientos}

Los autores agradecen a los 209 académicos que participaron voluntariamente en este estudio y a la Dra. Mariana Lazzaro-Salazar (Universidad Católica del Maule, Chile; Victoria University of Wellington, Nueva Zelanda) por su colaboración en la instancia de traducción de la CSES y el BIAJS.

\section{REFERENCIAS}

Aiken, L.S., West, S.G. y Reno, R.R. (1991), Multiple regression: Testing and interpreting interactions, Sage, Newbury Park, CA.

Bandura, A. (1997), Self-efficacy: The exercise of control, W. H. Freeman, New York.

Barrick, M. R. (2005), "Yes, personality matters: Moving on to more important matters", Human Performance, Vol. 18 No. 4, pp. 359-372.

Behling, O., y Law, K. S. (2000), Translating questionnaires and other research instruments: Problems and solutions, Sage, Thousand Oaks, CA.

Bernerth, J. B. y Aguinis, H. (2016), “A critical review and best-practice recommendations for control variable usage", Personnel Psychology, Vol. 69 No.1, pp. 229-283. 
Bowling, N. A., Khazon, S., Meyer, R. D., y Burrus, C. J. (2015), "Situational strength as a moderator of the relationship between job satisfaction and job performance: A metaanalytic examination", Journal of Business and Psychology, Vol. 30 No. 1, pp. 89104.

Buss, D. M. (2009), “An evolutionary formulation of person-situation interactions”, Journal of Research in Personality, Vol. 43 No. 2, pp. 241-242.

Brief, A. P., Butcher, A. H. y Roberson, L. (1995), "Cookies, disposition, and job attitudes: The effects of positive mood-inducing events and negative affectivity on job satisfaction in a field experiment", Organizational Behavior and Human Decision Processes, Vol. 62 No. 1, pp. 55-62.

Brislin, R. W. (1980), "Translation and content analysis of oral and written materials", En Triandis, H. C. y Berry, J. W. (Eds.), Handbook of cross-cultural psychology, Allyn \& Bacon, Boston, pp. 389-444.

Brown, T. A. (2006), Confirmatory factor analysis for applied research, Guildford Press, New York.

Byrne, B. M. (2001), "Structural equation modeling: Perspectives on the present and the future", International Journal of Testing, Vol. 1 No. 3-4, pp. 327-334.

Carver, C. S., Scheier, M. F. y Weintraub, J. K. (1989), “Assessing coping strategies: a theoretically based approach", Journal of Personality and Social Psychology, Vol. 56 No. 2, pp. 267-283.

Caspi, A., Roberts, B. W. y Shiner, R. L. (2005), "Personality development: Stability and change”, Annual Review of Psychology, Vol. 56 No. 1, pp. 453-484.

Chang, C. H., Ferris, D. L., Johnson, R. L., Rosen, C. C. y Tan, J. A. (2012), "Core selfevaluations: A review and evaluation of the literature", Journal of Management, Vol. 38 No. 1, pp. 81-128. 
Cohen-Charash, Y., y Spector, P. E. (2001), "The role of justice in organizations: A metaanalysis”, Organizational Behavior and Human Decision Processes, Vol. 86 No. 2, pp. 278-321.

Cohrs, J. C., Abele, A. E., y Dette, D. E. (2006), "Integrating situational and dispositional determinants of job satisfaction: Findings from three samples of professionals", The Journal of Psychology, Vol. 140 No. 4, pp. 363-395.

Collins, S. (2007), "Statutory social workers: Stress, job satisfaction, coping, social support and individual differences", British Journal of Social Work, Vol. 38 No. 6, pp. 11731193.

Costa, P. T, Jr. y McCrae, R. R. (1988), "Personality in adulthood: A six-year longitudinal study of self-reports and spouse ratings on the NEO Personality Inventory", Journal of Personality and Social Psychology, Vol. 54 No. 1, pp. 853-863.

Davis-Blake, A. y Pfeffer, J. (1989), "Just a mirage: The search for dispositional effects in organizational research", Academy of Management Review, Vol. 14 No. 3, pp. 385400.

Dierdorff, E. C., y Morgeson, F. P. (2013), “Getting what the occupation gives: Exploring multilevel links between work design and occupational values", Personnel Psychology, Vol. 66 No. 3, pp. 687-721.

Diestel, S., Wegge, J., y Schmidt, K. H. (2014), "The impact of social context on the relationship between individual job satisfaction and absenteeism: The roles of different foci of job satisfaction and work-unit absenteeism", Academy of Management Journal, Vol. 57 No. 2, pp. 353-382.

Dormann, C., Fay, D., Zapf, D., y Frese, M. (2006), “A state-trait analysis of job satisfaction: on the effect of core self-evaluations", Applied Psychology, Vol. 55 No. 1, pp. 27-51. 
Edwards, J. R., Scully, J. A., y Brtek, M. D. (2000), "The nature and outcomes of work: a replication and extension of interdisciplinary work-design research", Journal of Applied Psychology, Vol. 85 No. 6, pp. 860-868.

Fritzsche, B. A. y Parrish, T. J. (2005), “Theories and research on job satisfaction", En Brown, S. D. y Lent, R. W. (Eds.), Career development and counseling: Putting theory and research to work, Wiley, Hoboken, NJ, pp. 180-202.

Ferguson, T. D., y Cheek, R. (2011), "How Important Are Situational Constraints in Understanding Job Satisfaction?”, International Journal of Business and Social Science, Vol. 2 No. 22, pp. 221-227.

Fernández Lamarra, N. y Marquina, M. (2013), “La Profesión Académica en America Latina: Tendencias actuales a partir de un estudio comparado", Espacios en blanco. Serie indagaciones, Vol. 23 No. 1, pp. 99-117.

Fisher, C. D. (2000), "Mood and emotions while working: Missing pieces of job satisfaction?", Journal of Organization Behavior, Vol. 21 No. 1, pp. 185-202.

Flickinger, M., Allscher, M., y Fiedler, M. (2016), “The mediating role of leader- member exchange: a study of job satisfaction and turnover intentions in temporary work", Human Resource Management Journal, Vol. 26 No. 1, pp. 46-62.

Funder, D., Guillaume, E., Kumagai, S, Kawamoto, S., Sato, T. (2012), “The Person-situation Debate and the Assessment of Situations", The Japanese Journal of Personality, Vol. 21 No. 1, pp. 1-11.

Gagné, M., y Deci, E. L. (2005), “Self- determination theory and work motivation”, Journal of Organizational Behavior, Vol. 26 No. 4, pp. 331-362.

García de Fanelli, A. y Moguillansky, M. (2014), "La docencia universitaria en Argentina Obstáculos en la carrera académica”, Education Policy Analysis Archives, Vol. 22 No. 1 , pp. 1-18. 
Gillespie, N. A., Walsh, M. H. W. A., Winefield, A. H., Dua, J., y Stough, C. (2001), "Occupational stress in universities: Staff perceptions of the causes, consequences and moderators of stress", Work \& Stress, Vol. 15 No. 1, pp. 53-72.

Goh, Z., Ilies, R., y Wilson, K. S. (2015), “Supportive supervisors improve employees' daily lives: The role supervisors play in the impact of daily workload on life satisfaction via work-family conflict”, Journal of Vocational Behavior, Vol. 89 No. 1, pp. 65-73.

Goldberg, L. R. (1990), "An alternative "description of personality": the big-five factor structure", Journal of Personality and Social Psychology, Vol. 59 No. 6, pp. 12161229.

Grant, N., Wardle, J., y Steptoe, A. (2009), “The relationship between life satisfaction and health behavior: a cross-cultural analysis of young adults", International Journal of Behavioral Medicine, Vol. 16 No. 3, pp. 259-268.

Grant, A.M., Fried, Y. y Juillerat, T. (2011), "Work matters: Job design in classic and contemporary perspectives", En Zedeck, S., APA Handbook of Industrial and Organizational Psychology, American Psychological Association, Washington, DC.

Greenhaus, J. H., y Allen, T. D. (2011), “Work-family balance: A review and extension of the literature", Handbook of Occupational Health Psychology, Vol. 2 No. 1, pp. 165-183.

Hackman, J. R. y Oldham, G. R. (1976), "Motivation through the design of work: Test of a theory", Organizational Behavior and Human Performance, Vol. 16 No. 2, pp. 250279.

Hair, J., Anderson, R., Tatham, R., y Black, W. (1995), Multivariate data analysis, PrenticeHall, Englewood Cliffs, NJ.

Hambleton, R. K., Merenda, P. F., y Spielberger, C. D. (2006), Adapting Psychological and Educational Tests for Cross-Cultural Assessment, Lawrence Erlbaum Associates, Mahwah. 
Haney, C. y Zimbardo, P. G. (2009), "Persistent dispositionalism in interactionist clothing: Fundamental attribution error in explaining prison abuse", Personality and Social Psychology Bulletin, Vol. 35 No. 6, pp. 807-814.

Harter, S. (1990), "Causes, correlates, and the functional role of global self-worth: A lifespan perspective”, En Sternberg, R. J. y Kolligan, J. (Eds.), Competence considered, Yale University Press, New Haven, CT, pp. 67-97.

Harris, J. I., Winskowski, A. M. y Engdahl, B. E. (2007), “Types of workplace social support in the prediction of job satisfaction”, The Career Development Quarterly, Vol. 56 No. 2, pp. $150-156$.

Harrison, D. A., Newman, D. A., y Roth, P. L. (2006), "How important are job attitudes? Meta-analytic comparisons of integrative behavioral outcomes and time sequences", Academy of Management Journal, Vol. 49 No. 2, pp. 305-325.

Häusser, J. A., Mojzisch, A., Niesel, M., y Schulz-Hardt, S. (2010), “Ten years on: A review of recent research on the Job Demand-Control (-Support) model and psychological well-being”, Work \& Stress, Vol. 24 No. 1, pp. 1-35.

Heaney, C. A. y Israel, B. A. (2008), "Social networks and social support", Health Behavior and Health Education, Vol. 4 No. 1, pp. 189-210.

Hogan, R. (2009), "Much ado about nothing: The person-situation debate", Journal of Research in Personality, Vol. 43 No. 2, pp. 249.

Humphrey, S. E., Nahrgang, J. D., y Morgeson, F. P. (2007), "Integrating motivational, social, and contextual work design features: a meta-analytic summary and theoretical extension of the work design literature", Journal of Applied Psychology, Vol. 92 No. 5, pp. 1332-1353. 
Hsieh, H. H., y Huang, J. T. (2017), "Core self-evaluations and job and life satisfaction: the mediating and moderated mediating role of job insecurity", The Journal of Psychology, Vol. 151 No. 3, pp. 282-298.

Ilies, R., Schwind, K. M., Wagner, D. T., Johnson, M. D., DeRue, D. S., y Ilgen, D. R. (2007), "When can employees have a family life? The effects of daily workload and affect on work-family conflict and social behaviors at home", Journal of Applied Psychology, Vol. 92 No. 5, pp. 1368-1379.

Judge, T. A., Locke, E. A., y Durham, C. C. (1997), “The dispositional causes of job satisfaction: A core evaluations approach", Research in Organizational Behavior, Vol. 19 No. 1, pp. 151-188.

Judge, T. A., Locke, E. A., Durham, C. C. y Kluger, A. N. (1998), “Dispositional effects on job and life satisfaction: the role of core evaluations", Journal of Applied Psychology, Vol. 83 No. 1, pp. 17-34.

Judge, T. A., Bono, J. E. y Locke, E. A. (2000), "Personality and job satisfaction: the mediating role of job characteristics", Journal of Applied Psychology, Vol. 85 No. 2, pp. 237-249.

Judge, T. A., Erez, A., Bono, J. E. y Thoresen, C. J. (2002), “Are measures of selfesteem, neuroticism, locus of control, and generalized self-efficacy indicators of a common core construct?", Journal of Personality and Social Psychology, Vol. 83 No. 3, pp. 693-710.

Judge, T. A., Erez, A., Bono, J. E., y Thoresen, C. J. (2003), “The core self-evaluations scale: Development of a measure", Personnel Psychology, Vol. 56 No. 2, pp. 303-331.

Judge, T. A., Bono, J. E., Erez, A., y Locke, E. A. (2005), “Core self-evaluations and job and life satisfaction: the role of self-concordance and goal attainment", Journal of Applied Psychology, Vol. 90 No. 2, pp. 257-268. 
Judge, T. A., Heller, D., y Klinger, R. (2008a), “The dispositional sources of job satisfaction: A comparative test”, Applied Psychology, Vol. 57 No. 3, pp. 361-372.

Judge, T. A., Klinger, R., Simon, L. S., y Yang, I. W. F. (2008b), "The contributions of personality to organizational behavior and psychology: Findings, criticisms, and future research directions", Social and Personality Psychology Compass, Vol. 2 No. 5, pp. 1982-2000.

Judge, T. A., Ilies, R., y Zhang, Z. (2012), “Genetic influences on core self-evaluations, job satisfaction, work stress, and employee health: A behavioral genetics mediated model”, Organizational Behavior and Human Decision Processes, Vol. 117 No. 1, pp. 208-220.

Judge, T. A., y Zapata, C. P. (2015), “The person-situation debate revisited: Effect of situation strength and trait activation on the validity of the big five traits in predicting job performance", Academy of Management Journal, Vol. 58 No. 4, pp. 1-31.

Judge, T. A., Weiss, H. M., Kammeyer-Mueller, J. D., y Hulin, C. L. (2017), “Job attitudes, job satisfaction, and job affect: A century of continuity and of change", Journal of Applied Psychology, Vol. 102 No. 3, pp. 356-374.

Kammeyer-Mueller, J. D., Judge, T. A., y Scott, B. A. (2009), "The role of core selfevaluations in the coping process", Journal of Applied Psychology, Vol. 94 No. 1, pp. 177-195.

Kenrick, D. T., y Funder, D. C. (1988), "Profiting from controversy: Lessons from the personsituation debate", American Psychologist, Vol. 43 No. 1, pp. 23-34.

Kinman, G., Wray, S., y Strange, C. (2011), "Emotional labour, burnout and job satisfaction in UK teachers: The role of workplace social support", Educational Psychology, Vol. 31 No. 7, pp. 843-856. 
Klassen, R. M., y Chiu, M. M. (2010), 'Effects on teachers' self-efficacy and job satisfaction: Teacher gender, years of experience, and job stress", Journal of Educational Psychology, Vol. 102 No. 3, pp. 741-756.

Kristof-Brown, A. L., Zimmerman, R. D., y Johnson, E. C. (2005), “Consequences of individuals' fit at work: a meta-analysis of person-job, person-organization, persongroup, and person-supervisor fit”, Personnel psychology, Vol. 58 No. 2, pp. 281-342.

Lent, R. W., y Brown, S. D. (2006), "Integrating person and situation perspectives on work satisfaction: A social-cognitive view", Journal of Vocational Behavior, Vol. 69 No. 2, pp. 236-247.

Lewig, K. A., y Dollard, M. F. (2003), "Emotional dissonance, emotional exhaustion and job satisfaction in call centre workers", European Journal of Work and Organizational Psychology, Vol. 12 No. 4, pp. 366-392.

Mayer, J. D. (2007), “Asserting the definition of personality”, The Online Newsletter for Personality Science, Vol. 1 No. 1, pp. 1-4.

Mauno, S., Leskinen, E., y Kinnunen, U. (2001), "Multi- wave, multi- variable models of job insecurity: applying different scales in studying the stability of job insecurity", Journal of Organizational Behavior, Vol. 22 No. 8, pp. 919-937.

Meliá, J. et al. (2006), "Principios Comunes para la Evaluación de los Riesgos Psicosociales en la Empresa”, En Meliá, J. et al. (Eds.), Perspectivas de Intervención en Riesgos Psicosociales. Evaluación de riesgos, Foment del Treball Nacional, Barcelona, pp. 1336.

Meyer, R. D., Dalal, R. S., y Hermida, R. (2010), “A review and synthesis of situational strength in the organizational sciences", Journal of Management, Vol. 36 No. 1, pp. 121-140. 
Moncada, S., Llorens, C., y Kristensen, T. S. (2004), Método ISTAS 21 (CoPsoQ). Manual para la evaluación de riesgos psicosociales en el trabajo, Paralelo Ediciones, España.

Morgeson, F. P., y Humphrey, S. E. (2006), "The Work Design Questionnaire (WDQ): developing and validating a comprehensive measure for assessing job design and the nature of work", Journal of Applied Psychology, Vol. 91 No. 6, pp. 1321-1339.

Muñiz, J., Elosua, P., y Hambleton, R. K. (2013), “Directrices para la traducción y adaptación de los tests: segunda edición”, Psicothema, Vol. 25 No. 2, pp. 151-157.

Myers, I. B., McCaulley, M. H., Quenk, N. L., y Hammer, A. L. (1998), MBTI manual: A guide to the development and use of the Myers-Briggs Type Indicator, Consulting Psychologists Press Palo Alto, CA.

Nguyen, N. y Borteyrou, X. (2016), "Core self-evaluations as a mediator of the relationship between person-environment fit and job satisfaction among laboratory technicians", Personality and Individual Differences, Vol. 99 No. 1, pp. 89-93.

Nunnally, J. C. y Bernstein, I. H. (1994), Psychological theory, MacGraw-Hill, New York.

Ones, D. S., Dilchert, S., Viswesvaran, C., y Judge, T. A. (2007), "In support of personality assessment in organizational settings", Personnel Psychology, Vol. 60 No. 4, pp. 9951027.

Parker, S. K., Wall, T. D., y Cordery, J. L. (2001), "Future work design research and practice: Towards an elaborated model of work design", Journal of Occupational and Organizational Psychology, Vol. 74 No. 4, pp. 413-440.

Pervin, L. A., Cervone, D. y John, O. P. (2005), Personality: Theory and Research, John Wiley \& Sons, Hoboken, NJ.

Piccolo, R. F., Judge, T. A., Takahashi, K., Watanabe, N., y Locke, E. A. (2005), “Core selfevaluations in Japan: relative effects on job satisfaction, life satisfaction, and happiness", Journal of Organizational Behavior, Vol. 26 No. 8, pp. 965-984. 
Pickering, A. D. y Gray, J. A. (1999), “The neuroscience of personality”, En Pervin, L. A. y John, O. P. (Eds.), Handbook of personality: Theory and Research, Guilford Press, New York, pp. 277-299.

Podsakoff, P. M., MacKenzie, S. B., Lee, J. Y. y Podsakoff, N. P. (2003), “Common method biases in behavioral research: a critical review of the literature and recommended remedies", Journal of Applied Psychology, Vol. 88 No. 5, pp. 879-903.

Pujol-Cols, L., y Arraigada, M. (2017), "Propiedades psicométricas del Cuestionario de Riesgos Psicosociales Copsoq-Istas 21 y aplicación en docentes universitarios argentinos", Cuadernos de Administración, Vol. 30 No. 55, pp. 97-125.

Pujol-Cols, L. J., y Dabos, G. E. (2018), “Satisfacción laboral: una revisión de la literatura acerca de sus principales determinantes", Estudios Gerenciales, Vol. 34 No. 146, pp. 3-18.

Pujol-Cols, L. y Lazzaro-Salazar, M. (2018), "Psychosocial Risks and Job Satisfaction in Argentinian Scholars: Exploring the moderating role of Work Engagement", Journal of Work and Organizational Psychology, Vol. 34 No. 3, pp. 145-156.

Reisel, W. D., Probst, T. M., Chia, S. L., Maloles, C. M., y König, C. J. (2010), “The effects of job insecurity on job satisfaction, organizational citizenship behavior, deviant behavior, and negative emotions of employees", International Studies of Management \& Organization, Vol. 40 No. 1, pp. 74-91.

Rivero, A. G., y Dabos, G. E. (2017), “Gestión diferencial de recursos humanos: una revisión e integración de la literatura", Estudios Gerenciales, Vol. 33 No. 142, pp. 39-51.

Rode, J. C., Judge, T. A., y Sun, J. M. (2012), “Incremental validity of core self-evaluations in the presence of other self-concept traits: An investigation of applied psychology criteria in the United States and China", Journal of Leadership and Organizational Studies, Vol. 19 No. 3, pp. 326-340. 
Rotter, J. B. (1966), “Generalized expectancies for internal versus external control of reinforcement”, Psychological Monographs, Vol. 80, No. 1.

Salanova, M., Martínez, I. M., y Lorente, L. (2005), “Cómo se relacionan los obstáculos y facilitadores organizacionales con el burnout docente?: Un estudio longitudinal”, Revista de Psicología del Trabajo y de las Organizaciones, Vol. 21 No. 1-2, pp. 3754.

Siegrist, J. (1996), “Adverse health effects of high-effort/low-reward conditions", Journal of Occupational Health Psychology, Vol. 1 No. 1, pp. 27-41.

Skaalvik, E. M., y Skaalvik, S. (2014), “Teacher self-efficacy and perceived autonomy: Relations with teacher engagement, job satisfaction, and emotional exhaustion", Psychological Reports, Vol. 114 No. 1, pp. 68-77.

Spector, P. E., Chen, P. Y., y O'Connell, B. J. (2000), “A longitudinal study of relations between job stressors and job strains while controlling for prior negative affectivity and strains", Journal of Applied Psychology, Vol. 85 No. 2, pp. 211-218.

Srivastava, A., Locke, E. A., Judge, T. A., y Adams, J. W. (2010), “Core self-evaluations as causes of satisfaction: The mediating role of seeking task complexity", Journal of Vocational Behavior, Vol. 77 No. 2, pp. 255- 265.

Staw, B. M., y Cohen-Charash, Y. (2005), "The dispositional approach to job satisfaction: More than a mirage, but not yet an oasis", Journal of Organizational Behavior, Vol. 26 No. 1, pp. 59-78.

Stumpp, T., Muck, P. M., Hülsheger, U. R., Judge, T. A., y Maier, G. W. (2010), “Core selfevaluations in Germany: validation of a German measure and its relationships with career success", Journal of Applied Psychology, Vol. 59 No. 4, pp. 674-700.

Sunal, A. B., Sunal, O. y Yasin, F. (2011), “A comparison of workers employed in hazardous jobs in terms of job satisfaction, perceived job risk and stress: Turkish jean 
sandblasting workers, dock workers, factory workers and miners", Social Indicators Research, Vol. 102 No. 2, pp. 265-273.

Sverke, M., Hellgren, J., y Näswall, K. (2002), “No security: a meta-analysis and review of job insecurity and its consequences", Journal of Occupational Health Psychology, Vol. 7 No. 3, pp. 242-264.

Thomas, A., Buboltz, W. C., y Winkelspecht, C. S. (2004), "Job characteristics and personality as predictors of job satisfaction”, Organizational Analysis, Vol. 12 No. 2, pp. 205-219.

Thompson, E. R., y Phua, F. T. (2012), “A brief index of affective job satisfaction”, Group y Organization Management, Vol. 37 No. 3, pp. 275-307.

Tsaousis, I., Nikolaou, I., Serdaris, N., y Judge, T. A. (2007), “Do the core self-evaluations moderate the relationship between subjective well-being and physical and psychological health?”, Personality and Individual Differences, Vol. 42 No. 8, pp. 1441-1452.

Tziner, A., Waismal-Manor, R., Vardi, N., y Brodman, A. (2008), "The personality dispositional approach to job satisfaction and organizational commitment", Psychological Reports, Vol. 103 No. 2, pp. 435-442.

Unda, S., Uribe, F., Jurado, S., García, M., Tovalín, H. y Juárez, A. (2016), “Elaboración de una escala para valorar los factores de riesgo psicosocial en el trabajo de profesores universitarios", Revista de Psicología del Trabajo y de las Organizaciones, Vol. 32 No. 2, pp. 67-74.

Wrzesniewski, A., Dutton, J. E., y Debebe, G. (2003), "Interpersonal sensemaking and the meaning of work", Research in Organizational Behavior, Vol. 25 No. 1, pp. 93-135. 
Waltman, J., Bergom, I., Hollenshead, C., Miller, J., y August, L. (2012), "Factors contributing to job satisfaction and dissatisfaction among non-tenure-track faculty", The Journal of Higher Education, Vol. 83 No. 3, pp. 411-434.

Weir, K. (2013), “More than job satisfaction”, APA Monitor on Psychology, Vol. 44 No. 11, pp. 39.

Weiss, H. M. (2002), “Deconstructing job satisfaction: Separating evaluations, beliefs and affective experiences”, Human Resource Management Review, Vol. 12 No. 2, pp. 173194.

Wu, C. H., y Griffin, M. A. (2012), “Longitudinal relationships between core self-evaluations and job satisfaction”, Journal of Applied Psychology, Vol. 97 No. 2, pp. 331-342.

Ziegler, R., Hagen, B., y Diehl, M. (2012), "Relationship between job satisfaction and job performance: Job ambivalence as a moderator", Journal of Applied Social Psychology, Vol. 42 No. 8, pp. 2019-2040. 